\title{
Current state and trends in Canadian Arctic marine ecosystems: II. Heterotrophic food web, pelagic-benthic coupling, and biodiversity
}

\author{
Gérald Darnis • Dominique Robert • \\ Corinne Pomerleau • Heike Link • \\ Philippe Archambault • R. John Nelson • \\ Maxime Geoffroy • Jean-Éric Tremblay • \\ Connie Lovejoy • Steve H. Ferguson • Brian P. V. Hunt • \\ Louis Fortier
}

Received: 13 February 2012 / Accepted: 22 April 2012

(C) The Author(s) 2012. This article is published with open access at Springerlink.com

\begin{abstract}
As part of the Canadian contribution to the International Polar Year (IPY), several major international research programs have focused on offshore arctic marine ecosystems. The general goal of these projects was to improve our understanding of how the response of arctic marine ecosystems to climate warming will alter food web structure and ecosystem services provided to Northerners. At least four key findings from these projects relating to arctic heterotrophic food web, pelagic-benthic coupling and biodiversity have emerged: (1) Contrary to a long-standing paradigm of dormant ecosystems during the long arctic winter, major food web components showed relatively high level of winter activity, well before the spring release of ice algae and subsequent phytoplankton bloom. Such phenological plasticity among key secondary producers like zooplankton may thus narrow the risks of
\end{abstract}

G. Darnis $\cdot$ D. Robert $(\bowtie) \cdot$ M. Geoffroy $\cdot$ J.-É. Tremblay $・$ C. Lovejoy $・$ L. Fortier

Québec-Océan, Département de biologie, Université Laval, 1045 avenue de la Médecine, Québec, QC, Canada G1V 0A6

e-mail: dominique.robert@qo.ulaval.ca

C. Pomerleau $\cdot$ H. Link $\cdot$ P. Archambault

Institut des sciences de la mer de Rimouski, Université du Québec à Rimouski, 310 allée des Ursulines, Rimouski, QC, Canada G5L 3A1

R. J. Nelson

Institute of Ocean Sciences, Fisheries and Oceans Canada, 9860 West Saanich Road, P.O. Box 6000, Sidney, BC, Canada V8L 4B2

S. H. Ferguson

Freshwater Institute, Fisheries and Oceans Canada, 501 University Crescent, Winnipeg, MB, Canada R3T 2N6

B. P. V. Hunt

Department of Earth and Oceans Sciences, University of British Columbia, 6339 Stores Road, Vancouver, BC, Canada V6T $1 Z 4$ 
extreme mismatch between primary production and secondary production in an increasingly variable arctic environment. (2) Tight pelagic-benthic coupling and consequent recycling of nutrients at the seafloor characterize specific regions of the Canadian Arctic, such as the North Water polynya and Lancaster Sound. The latter constitute hot spots of benthic ecosystem functioning compared to regions where zooplankton-mediated processes weaken the pelagic-benthic coupling. (3) In contrast with another widely shared assumption of lower biodiversity, arctic marine biodiversity is comparable to that reported off Atlantic and Pacific coasts of Canada, albeit threatened by the potential colonization of subarctic species. (4) The rapid decrease of summer sea-ice cover allows increasing numbers of killer whales to use the Canadian High Arctic as a hunting ground. The stronger presence of this species, bound to become a new apex predator of arctic seas, will likely affect populations of endemic arctic marine mammals such as the narwhal, bowhead, and beluga whales.

\section{Introduction}

From fisheries to the renewal of oxygen and from ecotourism to the sequestration of greenhouse gases, marine ecosystems and the biota they support provide humans with multiple services. Communities in the Canadian Arctic are particularly dependent upon the sea and the sea ice (e.g. Hovelsrud et al. 2008; Zeller et al. 2011). For instance, arctic marine ecosystems provide Inuit with necessary food and nutrition, and a diet rich in omega3 fatty acids and selenium that provides protection against ailments such as cardiovascular diseases, diabetes, obesity and cancer (e.g. Bjerregaard et al. 2004). The unique fauna of the Arctic Ocean supplies many other ecosystem services such as hides and furs, heating oil, substrates for tools and sculpture (e.g., bone, ivory), inspiration for the arts, ecotourism revenues, recreation, social and spiritual cohesion through the sharing of food and knowledge, and intergenerational bonding through the teaching of fishing and hunting. Overall, the open and ice-covered waters of the Arctic Ocean as well as the plankton, fish, mammals and birds they harbour underpin a large fraction of the economy, culture, tradition, and wellbeing of northerners.

Our capacity to anticipate how the ongoing transformation of the Arctic Ocean will affect, either negatively or positively, the quality and socio-economic value of these services, depends on our understanding of the response of marine ecosystems to the double pressure of climate change and industrialization. As part of the Canadian contribution to the International Polar Year (IPY), major international research programs have focused on offshore marine ecosystems. The scientific rationale and objectives of these programs were rooted in earlier advances in our comprehension of the ecology of arctic seas, which are summarized here.

The extreme climate that has prevailed over the Arctic Ocean for several million years has shaped unique marine ecosystems characterized by organisms that are adapted to frigid temperatures; the alternation between polar night and midnight sun; a perennial or seasonal sea ice cover, limiting nutrients in the stratified surface layer; and an extremely pulsed cycle of primary production (Fig. 1). Spectacular examples of these hyper-specialists endemic to arctic seas are the polar bear, the walrus and the narwhal, all of which depend on sea ice for hunting, reproduction and/or protection (Stirling 1997; Tynan and DeMaster 1997). These predators and several other large vertebrate carnivores, including fish and birds, in turn rely on the energy transferred from the microalgal primary producers by the lower trophic levels of the food chain. The invertebrates that effect this transfer have developed sophisticated life history strategies to survive and reproduce in a pelagic realm above which sea ice and an 


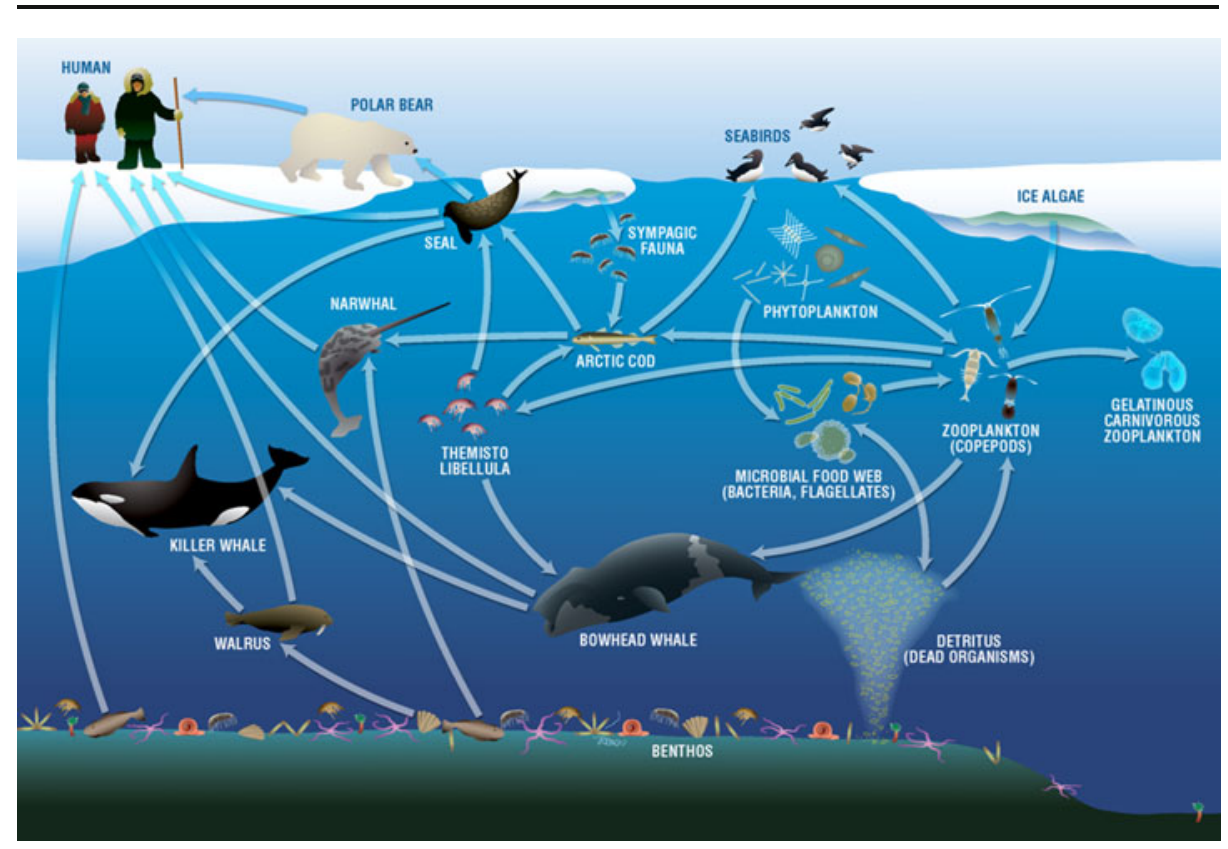

Fig. 1 Schematic representation of the Canadian arctic marine food web, with a transition from coastal to oceanic ecosystem (left to right)

overlying snow mantle block photosynthesis for up to 10 months of the year (Conover and Huntley 1991).

Large phytoplankton cells, such as diatoms and dinoflagellates, are the primary food of zooplankton, the biomass of which is dominated by the large suspension feeders Calanus glacialis and C. hyperboreus in all arctic seas (Arashkevich et al. 2002; e.g. Auel and Hagen 2002; Darnis et al. 2008). By exerting heavy grazing pressure on the microalgal primary producers, large herbivorous copepods have the capacity to build in a few weeks huge lipid reserves, mostly as wax esters, that often exceed $60 \%$ of their dry mass at the end of the feeding season (Falk-Petersen et al. 2009). Markers of dinoflagellates, e.g., the omega-3 polyunsaturated fatty acid 22:6n3 concentrated in the wax esters of copepods, are essential constituents of the polar lipids in the cell membranes of all animals where they ensure fluidity, compressibility and permeability (Falk-Petersen et al. 2009). Thus, the high energy lipid compounds and essential fatty acids concentrated in Calanus species make them key drivers of the transfer of energy through arctic marine ecosystems. Furthermore, these same species perform long-range seasonal vertical migrations to depths of several hundred meters where the late developmental stages overwinter in a resting state for much of the ice-covered period (Ashjian et al. 2003; Hirche 1997). Mortality and respiration in the populations of Calanus spp. overwintering at depth are suspected to contribute significantly to the biogeochemical cycle of carbon, particularly the export of carbon to the deep Arctic Ocean.

By contrast, the small, numerically dominant copepods (Oithona similis, Triconia borealis, Pseudocalanus spp., and Microcalanus spp.) do not perform extensive vertical migrations in the Arctic (Fortier et al. 2001). Their low internal energy reserves and high turnover rates compel these small species to remain active year-round. By feeding opportunistically throughout the winter season on variable food sources, small zooplankters, along 
with microzooplankton, could be the major grazers in the detrital pathway that sets in late summer or early fall in the arctic pelagic ecosystem (Forest et al. 2008).

The arctic cod Boreogadus saida is likely the main consumer of arctic copepods. In turn, it is the staple of the seals, whales, and marine birds that account for many of the services provided by arctic marine ecosystems. This fish could effect as much as $75 \%$ of the transfer of energy between the zooplankton and vertebrate predators (Welch et al. 1992). Arctic cod inhabit the ice pack for part of their life cycle (Gradinger and Bluhm 2004) and form large overwintering aggregations at depth during the ice-covered season (Benoit et al. 2008). Another ubiquitous consumer of copepods is the hyperiid amphipod Themisto libellula that funnels a significant fraction of the energy between the plankton and the higher trophic levels in ice covered seas (Dalpadado 2002; Welch et al. 1992).

Recently, the powerful tools of molecular biology have been applied to the study of biodiversity in arctic seas (Radulovici et al. 2010). These new approaches have revealed a surprising diversity including new taxa of bacterioplankton and archaeans (Galand et al. 2009a; e.g. Kirchman et al. 2009), eukaryotic microbes (Lovejoy and Potvin 2011; Lovejoy et al. 2007), and gregarine parasites of amphipods (Prokopowicz et al. 2010). The precise role of these recently discovered assemblages in the pelagic marine food webs and in the cycling of organic matter remains obscure. As well, benthic processes and biodiversity are not yet well resolved for the arctic seafloor although increased attention has been given in recent years to study the coupling between pelagic production and benthic carbon turnover (Morata et al. 2008; Renaud et al. 2007b).

Describing new species and their ecological roles, quantifying carbon and energy fluxes in the ecosystem, documenting the annual cycle of ecological processes, identifying hotspots of biological production, and contrasting the ecology of the different arctic seas are the objectives shared by several international and multidisciplinary research efforts that contributed to the Canadian IPY program. In this review, we present a selection of preliminary research results and distil some of the main findings on arctic marine ecosystems acquired through three major IPY projects: the Circumpolar Flaw Lead System Study (CFL); Canada's Three Oceans (C3O); and Global Warming and Arctic Marine Mammals (GWAMM) (see Tremblay et al. 2012 for scope of projects). We also provide an up-todate status of knowledge on Arctic marine biodiversity, gained from the CHONe and Arctic Census of Marine Life initiatives.

\section{Results and discussion}

The objective of this section is to summarize the main discoveries emerging from Canadianled research carried out during IPY. The largest portion of research effort has focused on understanding the spatio-temporal variability in food web processes (CFL and C3O projects). The IPY also provided the opportunity for a full assessment of marine ecosystem biodiversity in the Canadian Arctic through the Arctic Census of Marine Life (Bluhm et al. 2011a). Finally, we present results illustrating how the top predators (marine mammals) assemblage is likely to be affected by the decrease of sea ice cover and the expected climatedriven changes in primary and secondary production (GWAMM project).

\subsection{The pelagic food web during winter}

A long-lived paradigm in polar oceanography is that arctic pelagic ecosystems, characterized by short food webs, remain in a dormant state throughout most of the winter season beneath 
the sea-ice cover, which can last $8-10$ months in some regions. Among the reasons responsible for this now increasingly challenged view is the high seasonality of marine primary production that is strongly constrained to the short time window of a few weeks when snow melt and ice break-up allow for photosynthetically active radiation to reach the surface water column (Tremblay et al. 2012). Another important potential explanation, however, is the paucity of studies devoted to the long winter season at high latitudes, during which poor light and hostile ice-infested waters render sampling extremely costly and difficult. With the Canadian led IPY-CFL sampling program, new highlights on winter ecological processes and confirmation of some of the earlier observations made during previous and scarce overwintering scientific studies help to refine our understanding of the structure and functioning of the arctic marine ecosystem.

\subsubsection{The winter microbial food web}

Bacterioplankton winter production Despite the absence of significant pelagic photosynthetic activity during the wintertime, the waters of the Amundsen Gulf host relatively high bacterial biomass sustained by low production, albeit sufficient to compensate for mortality (Forest et al. 2011). The maintenance of such a baseline level of bacterioplankton cell abundance and activity throughout winter had also been observed in neighbouring Franklin Bay (Garneau et al. 2008), the Canada Basin (Sherr et al. 2003) and in Kongsfjorden on the west coast of Svalbard (Rokkan Iversen and Seuthe 2011). For the more coastal Franklin Bay, Garneau et al. (2008) suggested that winter bacterial communities are capable of fuelling a great portion of their production with terrigenous refractory organic substrates such as coloured dissolved organic matter (CDOM), carried to the region by runoff from the Mackenzie, Horton and Hornaday rivers. In the less river-influenced Amundsen Gulf, similar to the Beaufort Sea in general, the largest pool of dissolved organic matter (DOM) is in the cold Pacific halocline at depths between 40 and $200 \mathrm{~m}$ (Forest et al. 2011). Interestingly, bacterial abundance maxima and relatively high production were often found at $100 \mathrm{~m}$ or deeper during the 2003-2004 overwintering period in Franklin Bay (Garneau et al. 2008). We could thus expect efficient metabolizers of CDOM, such as representatives of the Cytophaga-Flavobacterium cluster (Kirchman 2002), to make up a substantial share of the winter bacterial community at intermediate depths in the southeastern Beaufort Sea. A study of the phylogenetic composition of the bacterioplankton in autumn on the Mackenzie Shelf revealed the widespread distribution of this group (Garneau et al. 2006) over this CDOM-laden region strongly influenced by the Mackenzie River (Retamal et al. 2007). Sala et al. (2008) described a markedly high bacterial metabolic diversity in the winter assemblages of Franklin Bay compared to spring-summer, suggesting that the former are capable of exploiting a broad array of complex carbon sources beneath the ice. Carnivorous and detritus feeding by zooplankton could also have supplied labile dissolved compounds to the bacteria prior to the spring primary production, as indicated by the significant correlation between bacterial production and zooplankton production (Forest et al. 2011). In addition, a recent study showed that other phylogenetically diverse psychrophylic strains of arctic bacteria are able to directly assimilate $\mathrm{CO}_{2}$ in dark and nutrient-deprived winter conditions (Alonso-Saez et al. 2010) presumably from the exploitation of metabolic processes such as nitrification (Galand et al. 2009b). This high flexibility in the use of labile to refractory organic compounds at a time of low and extremely variable food availability is certainly the key to the maintenance of an active microbial food web throughout winter. 
Heterotrophic protists' trophic diversity and parasitism The arctic pelagic protist assemblages are composed of a diversity of photosynthetic, mixotrophic and heterotrophic unicellular eukaryotes (Lovejoy et al. 2011). For the winter period though, the communities are generally dominated by heterotrophic microbes that remain active throughout this dark period, as revealed by microscopic and phylogenetic analyses (Rokkan Iversen and Seuthe 2011; e.g. Terrado et al. 2011; Terrado et al. 2009). Until the onset of elevated primary production, alveolate taxa, regrouping ciliates, apicomplexans, and dinoflagellates, are the most represented in the ribosomal RNA (rRNA) gene and rRNA clone libraries from mesopelagic and surface waters of the southeastern Beaufort Sea (Terrado et al. 2011; Terrado et al. 2009).

During the CFL sampling program in the Amundsen Gulf, sequences representative of parasitic alveolates, such as the dinoflagellates Syndinium and Hematodinium known for infecting zooplankton, were only recovered before April (Terrado et al. 2011). The same temporal pattern existed for the identification of active members of the ciliate family Phyllopharyngea, a group that was for the first time reported in the Arctic, and that counts among its members parasites of zooplankton. Interestingly, severely ciliate-infected copepods of the genus Calanus were occasionally found in late winter during sorting tasks of live organisms for experiments (G. Darnis, unpublished data). Moreover, Prokopowicz et al. (2010) documented higher infection of the amphipod Themisto libellula by an unidentified ciliate parasite in the Amundsen Gulf and Mackenzie shelf than on the continental slope of the southeastern Beaufort sea. The higher proportion of ciliate-infected amphipods in longterm sediment traps than in net collections suggested that these animals survived poorly and sank quickly toward the sea floor. These authors also described a new gregarine parasite species named Ganymedes themistos, belonging to the phylum Apicomplexa. This alveolate parasite of the body cavity of T. libellula did not seem to have a deleterious effect on its host. In the 2003-2004 winter, the mesopelagic layer of Franklin Bay hosted a diverse assemblage of uncultivated putative parasitic alveolates similar to those reported from Amundsen Gulf during the IPY-CFL study over the same season (Terrado et al. 2009). Interestingly, the 2004 microbial community had been advected into deeper Franklin Bay with Pacific halocline water from the Amundsen Gulf in December. Thus, this strong and persistent signal of a parasitic component within the microbial food web seems to indicate that parasitism is indeed an important process in winter. Winter bacterivory by heterotrophic dinoflagellates and ciliates was rather low but sufficient to control bacterial production (Forest et al. 2011; Vaqué et al. 2008). As reported in earlier studies, sequences of the small Prasinophyte $(<2 \mu \mathrm{m})$ Micromonas were recovered both in the rRNA gene and rRNA clone libraries in the Amundsen Gulf, indicating that this key component of the microbial food web remained active throughout winter (Terrado et al. 2011). The small autotrophic Micromonas cells could have thus served as prey for the heterotrophic flagellates. Inefficient grazing and parasitic mortality could be among the sources of labile dissolved organic carbon (DOC) for the bacteria during the dark winter when no photosynthesis can occur.

Metazoan microzooplankton $(50-200 \mu \mathrm{m})$ winter production One of the most striking patterns of the zooplankton dynamics in Amundsen Gulf was a period of extremely high abundance of early developmental stages of the smallest copepod species in the midst of winter 2008 (Fig. 2a). From the end of January to mid-March, the number of nauplii of Oithona/Oncaeidae copepods averaged 504,580 $\pm 316,936$ (mean \pm 1 SD) individuals $\mathrm{m}^{-2}$, but only $367,237 \pm 429,522$ individuals $\mathrm{m}^{-2}$ in the period corresponding to the springsummer season of high biological production. Although not significant because of the high variability, the difference between these two figures suggests that high copepod production occurs prior to the onset of primary production. 
Fig. 2 Time series of a integrated abundances of nauplii of Oithona/ Oncaeidae, b egg sacs detached from females of Oithona similis and Triconia/Oncaea, c females and d males of Oncaea spp., Oithona similis and Triconia borealis. Stations selected for the time series were restricted to depths over $250 \mathrm{~m}$ in Amundsen Gulf (Darnis et al., in prep)
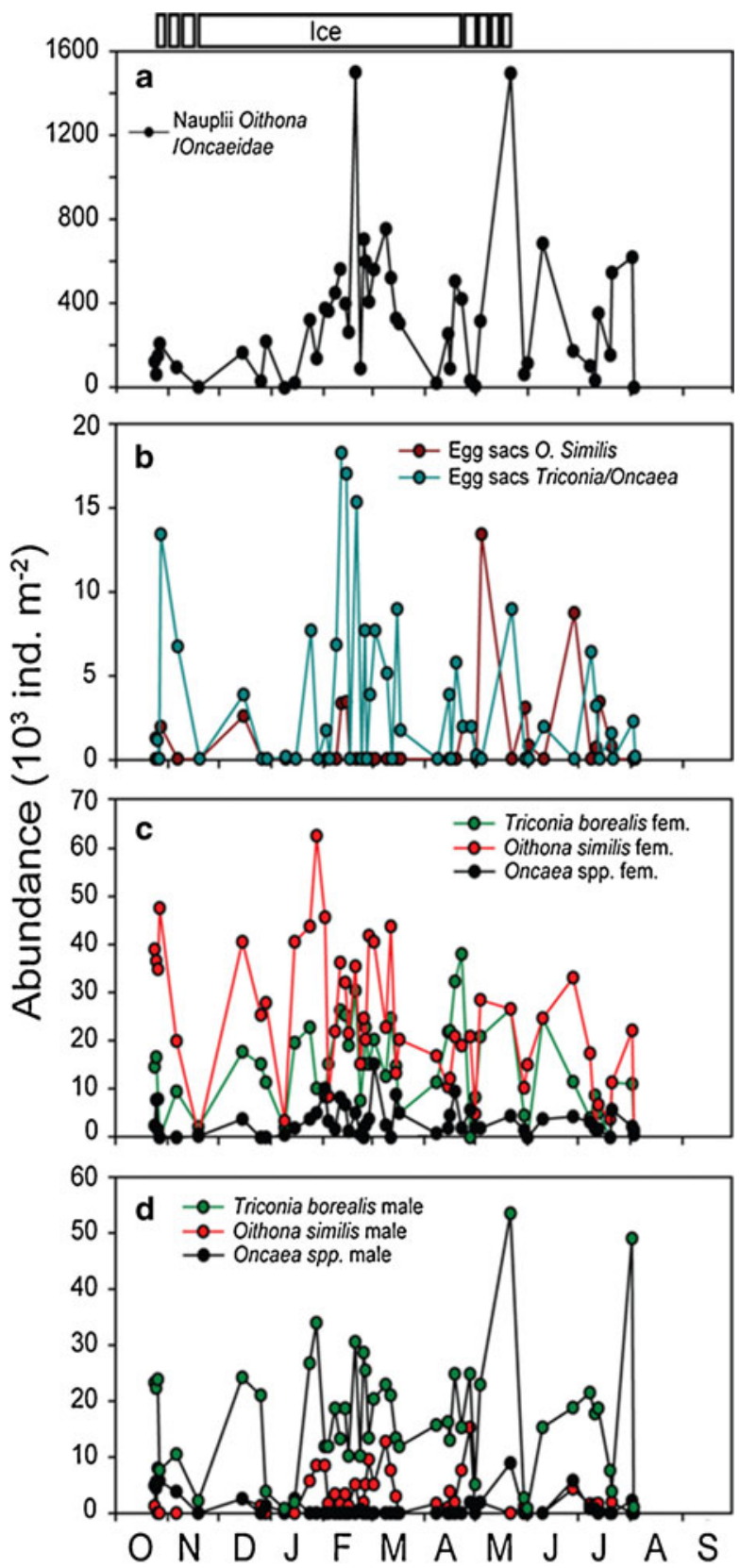

In contrast to the Amundsen Gulf during the IPY, a clear seasonal pattern was observed in the production of the small cyclopoid Oithona similis in the western Arctic and central Barents Sea (Arashkevich et al. 2002; Ashjian et al. 2003). The start of the period of highest abundances of cyclopoid nauplii coincided with the phytoplankton bloom although young stages indicative of reproduction for Oithona similis were also observed in winter in these regions. Furthermore, the abundances of nauplii found by these studies in March were 
generally less than one-third that found in Amundsen Gulf during the winter two-month peak production. Due to the lack of definite identification criteria, we did not try to allocate the counted small copepod nauplii to either of the cyclopoid Oithona similis or to the poecilostomatoids Triconia borealis or Oncaea spp. encountered in the region. Nevertheless, two main reasons led us to think that the winter nauplii belonged to Triconia borealis. First, most of the egg sacs detached from the gravid females by rough net sampling, and recovered in the samples, were of the size produced by Triconia borealis or Oncaea spp. (Fig. 2b), which are smaller than the egg sacs of Oithona similis. Second, the adult stages of Oncaea spp. were found in very low abundance at all times (Fig. 2c, d) and, thus, would have contributed little to the overall Oithona/poecilostomatoid production.

Little is known about the feeding ecology of T. borealis, but based on the morphology of their mouth parts it is assumed that they feed on particles attached to large surfaces such as appendicularian houses or phytoplankton and gelatinous aggregates (Wickstead 1962). There are indications that they are also carnivorous and semi-parasitic, preying on nauplii and sucking body fluids from larger zooplankton like large copepods, appendicularians and chaetognaths (Go et al. 1998; Kattner et al. 2003). Feeding on sinking fecal pellets and other detrital material is another strong possibility (Green and Dagg 1997; Skjoldal and Wassmann 1986). In fact, the large plasticity in the feeding strategy of T. borealis might well be one of the main explanations for its high reproductive success in winter 2008. The low specific respiration characteristic of Oncaeidae (Nishibe and Ikeda 2008) might have contributed to its strong reproduction as well by permitting this small copepod to allocate a substantial fraction of its internal energy to reproductive output at this time of variable and low food availability. However, the food sources that could have fuelled this winter pulse in reproduction are still not completely resolved. But, as already mentioned by Garneau et al. (2008) to explain the low but steady heterotrophic bacterial production in winter 2004, hydrological events such as convective mixing during ice formation in the highly dynamic polynya complex in the Amundsen Gulf and the passage of anticyclonic eddies (Barber et al. 2010) possibly provided detritus exploitable by attached bacterial communities. Such a carbon source could in turn be used efficiently by $T$. borealis. However, further investigation is needed to resolve the links between small detritivorous copepods and the microbial food web.

\subsubsection{Mesozooplankton activity during the dark season}

The IPY-CFL sampling program provided a rare opportunity to study zooplankton seasonal migration and physiological traits during the poorly documented winter season. By resolving vertical distribution and respiratory carbon loss over a quasi-annual cycle, Darnis and Fortier (2012) assessed the relative importance of two zooplankton size classes in the pelagic food web.

Mesozooplankton composition in the southeastern Beaufort Sea The Amundsen Gulf, and the southeastern Beaufort Sea in general (Darnis et al. 2008), host a mesozooplankton assemblage typical of arctic waters (Arashkevich et al. 2002; Ashjian et al. 2003; Auel and Hagen 2002) with a composition strongly dominated by copepods. Although much less abundant than the small organisms, the fraction of large zooplankton $(>1000 \mu \mathrm{m})$ was seven times more important in terms of biomass than the fraction of small zooplankton (200$1000 \mu \mathrm{m}$ ) during the 2007-2008 overwintering period. The herbivorous copepod Calanus hyperboreus represented most of the large zooplankton biomass with $51 \%$ of the share, followed by its congener C. glacialis (19\%) and the omnivore Metridia longa (13\%). The 
small size fraction biomass, on the other hand, was dominated by young copepodite stages (CI-CIII) of C. glacialis and Metridia longa with shares of 48 and $30 \%$, respectively. In contrast with the small organisms that distributed rather uniformly over the water column in all seasons, the Calanus-dominated large zooplankton were concentrated at depth from the start of the CFL sampling (late October 2007) to late April 2008.

Winter dynamics of the zooplankton small size fraction Small copepod species and young stages of large species are generally poorer in internal energy reserves than the large overwintering copepods. We would thus expect to find more opportunistic and active feeders in the small size fraction in winter. Over a quasi-annual cycle, the specific respiratory carbon loss of small zooplankton was variable as an indication of opportunistic foraging behaviour, and did not display the clear seasonal pattern observed in the large organisms (Darnis and Fortier 2012). Moreover, their diffuse distribution in the water column and their high specific respiration from the start of the CFL sampling in October until January suggested that they were actively feeding in autumn and early winter. With much of the large size fraction already in a resting stage at this time, small organisms were most likely the main zooplankton interceptors of the particulate organic carbon (POC) flux below $100 \mathrm{~m}$ depth. Furthermore, they may have exerted a significant top-down control on heterotrophic protists that usually reach maximum biomass in autumn. The assessment of the grazing impact of small zooplankton on winter protist assemblages, however, remains to be carried out.

Calanus hyperboreus in the winter pelagic food web The low specific respiration (per unit mass) of the large organisms until mid-March indicated that the bulk of the zooplankton was in a resting stage (so-called diapause) during the major part of the overwintering period. In the deep layers of the water column, the dominant Calanus hyperboreus and C. glacialis were then presumably using part of their lipid reserves to fuel basal metabolism. While still at depth, specific respiration of large zooplankton increased steeply and nearly doubled after mid-March. Interestingly, this arousal of large zooplankton occurred at least one month prior to any measurable chlorophyll a (Chl $a$ ) in the water column (Forest et al. 2011), and also ahead of a significant ice algal biomass in the sea-ice matrix at the surface (Wold et al. 2011). However, the increase in zooplankton activity coincided with the peak of Calanus hyperboreus egg production (50-66 eggs female ${ }^{-1} \mathrm{~d}^{-1}$ ) and a period of high abundance of Calanus eggs and nauplii averaging 30,316 $\pm 15,072$ and 25,900 $\pm 13,922$ individuals $\mathrm{m}^{-2}$, respectively for the month of March (Fig. 3). These youngest stages of C. hyperboreus should certainly play an important role in the pelagic food web by providing lipid-rich and easy prey to the omnivorous and carnivorous components of the large zooplankton.

Fig. 3 Time series of total water column abundance of Calanus spp. eggs and nauplii at stations $>250 \mathrm{~m}$ depth in the Amundsen Gulf (Darnis et al., in prep)

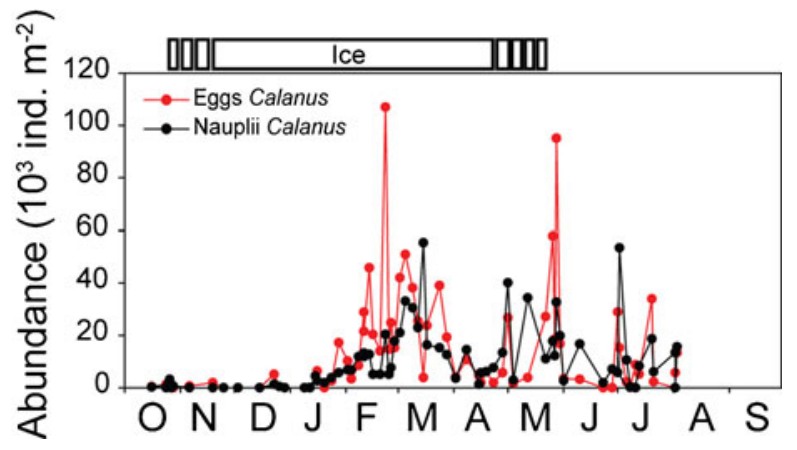


Enhanced feeding activity of large carnivorous zooplankton would thus explain to some extent the overall increase in zooplankton metabolism and possible production at a time of otherwise food shortage. Just as Conover and Huntley (1991) report in their thorough review on the life strategy of copepods under polar sea ice, a large number of females of the codominant Metridia longa were found to have orange guts in late March and early April 2008 as a result of feeding on $C$. hyperboreus eggs. Interestingly, these observations corresponded well with the timing of $C$. hyperboreus first reproductive events in the Amundsen Gulf, recorded by egg production experiments (G. Darnis, unpublished data).

Not too surprisingly, other omnivorous and carnivorous zooplankton species were also reproducing at depth in March, as was observed in the northern Barents Sea in 2003 (Hirche and Kosobokova 2011). Females of the large predatory copepod Paraeuchaeta glacialis bore egg sacs and their nauplii could be found in relatively great numbers in the water column, the same for females of the mesopelagic omnivore Gaidius spp. Furthermore, many chaetognaths of the two species Parasagitta elegans and Eukronhia hamata had gonads in an advanced state of maturation, and young stages of the jellyfish Aglantha digitale contributed to the composition of the small size fraction in late winter. A similar pattern of zooplankton reproduction prior to the onset of primary production was reported for European arctic peripheral regions such as the northern Barents, Kara and White seas (Kosobokova, K., pers. comm.). Therefore, by filling gaps in our knowledge of the winter trophodynamics among zooplankton in the southeastern Beaufort Sea, the IPY-CFL observations help achieve an improved pan-arctic perspective on the functioning of this unique pelagic food web. One of the important lessons, strengthened by the new studies, is that not the entire zooplankton production is directly tied to the timing of pelagic primary production, since a significant portion of the secondary production occurs in winter. Indeed, in the deep layers of the arctic seas, the reproduction of the herbivore Calanus hyperboreus, solely fuelled by its huge lipid reserves, ends before the release of ice algae by ice melt and subsequent spring phytoplankton bloom in the surface water column (Hirche and Niehoff 1996; G. Darnis, unpublished data from Franklin Bay and the Amundsen Gulf). We further hypothesize that, by supplying prey to the system, the early reproduction of this key species partially sustains the late winter production of zooplankton at higher trophic levels.

\subsubsection{Winter aggregations of arctic cod}

Despite the central role it plays in the arctic marine ecosystem, little is known about seasonal migrations and distribution patterns of arctic cod Boreogadus saida. Knowledge is particularly limited during the spawning season in winter due to the inherent difficulty of sampling fish under the ice cover (Mueller et al. 2006). Despite the scarcity of direct observations, evidence for the existence of large arctic cod aggregations in winter was traditionally derived from the intensive predation rate estimated from the stomach content of marine mammals and birds later in the season (Welch et al. 1992). Based on the continuous operation of an EK60 echosounder from the CCGS Amundsen at a single overwintering site in 2003-2004 (CASES program), and on the validation of acoustic data by net sampling, Benoit et al. (2008) confirmed the presence of large arctic cod aggregations in Franklin Bay at the southern boundary of Amundsen Gulf during winter. The authors hypothesized that arctic cod were distributed in the deep Pacific Halocline (PH) mainly to avoid visual predators and the colder temperatures of the Polar Mixed Layer (PML). With the CCGS Amundsen icebreaker remaining mobile throughout the winter of 2007-2008, the IPY-CFL project provided the unique opportunity of mapping arctic cod winter distribution at a wider spatiotemporal scale and testing if the results obtained by Benoit et al. (2008) apply to the entire 
Amundsen Gulf. By comparing the vertical distribution of arctic cod resolved with the echosounder to that of mesozooplankton prey determined with a Hydrobios multinet sampler, we also tested the hypothesis that prey availability was an important determinant of arctic cod distribution at depth during winter.

During the winter of 2007-2008, a total of ten dense polar cod aggregations were detected mainly in the deep Atlantic Layer (AL), including 13 integrated biomass peaks (Geoffroy et al. 2011). Estimated polar cod biomass peaked in February and March, where aggregations were twice as large as during the remainder of the winter (Fig. 4). Target strength (TS) analysis of individual fish detected at the surface of aggregations yielded an average estimated size of $7.40 \mathrm{~cm}$, consistent with the results of Benoit et al. (2008) who found that small fish tended to distribute on top of aggregations due to competitive exclusion.

Through stomach content analysis of individuals sampled with trammel nets during the CASES overwintering mission, Benoit et al. (2010) determined that the main prey of adult arctic cod captured under the ice cover of the southeastern Beaufort Sea consist of the calanoid copepods Calanus hyperboreus, Metridia longa and C. glacialis. These copepods typically comprise the bulk of biomass in the deep AL and PH of Amundsen Gulf in winter (Darnis et al. 2008; Darnis and Fortier 2012). In general, we observed that the winter vertical distribution of arctic cod coincided with that of its zooplankton prey in the AL of Amundsen Gulf (Geoffroy et al. 2011). An anticyclonic eddy affecting the area from 24 to 31 January
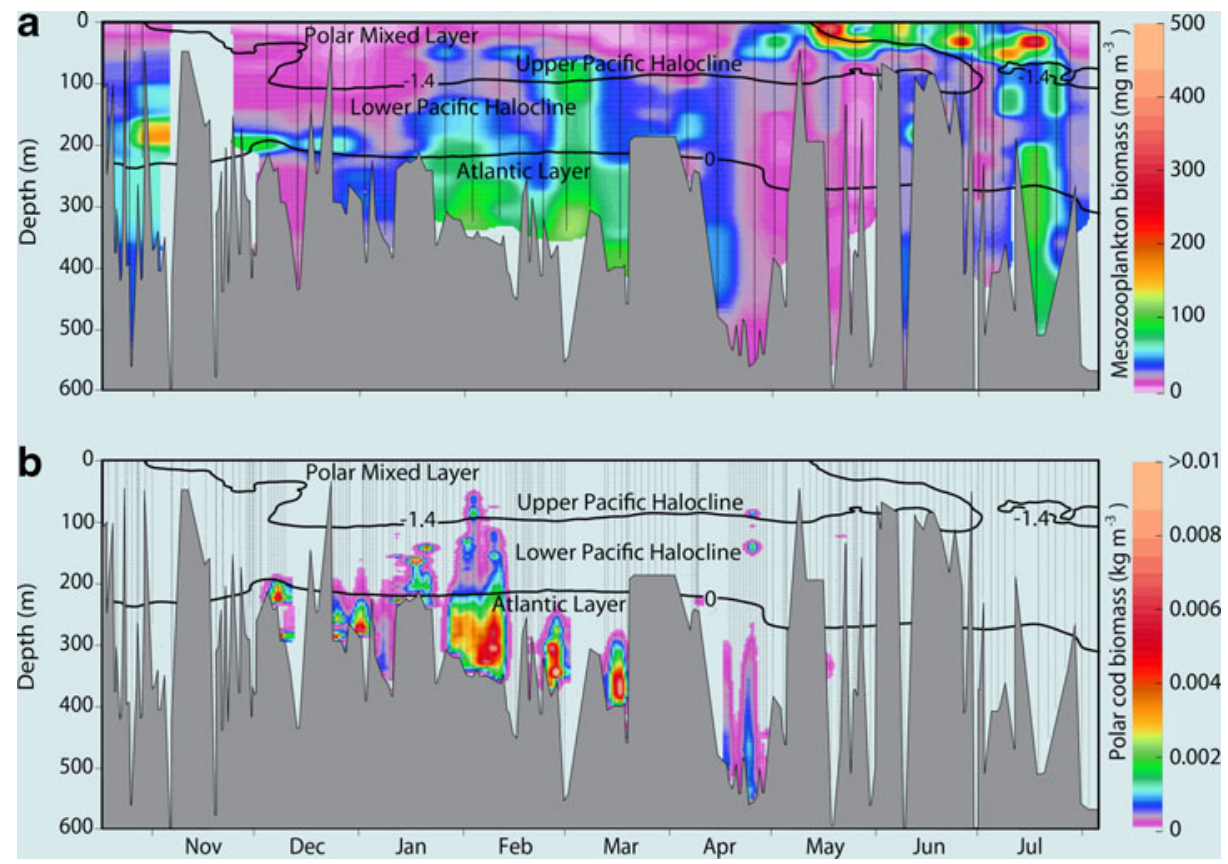

Fig. 4 Time-depth section of large (>1 mm) mesozooplankton biomass (a) and arctic cod biomass (b) along the track of the CCGS Amundsen in the Amundsen Gulf from 18 October 2007 to 4 August 2008. The $-1.4^{\circ} \mathrm{C}$ isotherm indicates the boundary between the upper and lower layers of the Pacific Halocline. The $0{ }^{\circ} \mathrm{C}$ isotherm separates the Pacific Halocline and the Atlantic layer. The grey area represents sea bottom. From Geoffroy et al. (2011) 
(Barber et al. 2010) likely drove an atypical incursion of mesozooplankton in the PH in late January and early February. Interestingly, a relatively large portion of the arctic cod population, mainly comprising small fish, followed their zooplankton prey in the PH during this transient event (Fig. 4) (Geoffroy et al. 2011). Arctic cod started to leave the AL in April, and the last aggregation was observed in late April coincident with the development of the phytoplankton bloom (Forest et al. 2011), and the colonization of the PML by zooplankton prey (Geoffroy et al. 2011). The ice-water interface acts as a barrier that limits predation on the buoyant arctic cod eggs and young stages, hiding in ice interstices (Gradinger and Bluhm 2004). This tight relationship between arctic cod distribution during spawning and the ice cover suggests that the ongoing lengthening of the ice-free season will affect recruitment by reducing the duration of the spawning season.

The vernal colonization of the surface layer by zooplankton in late April may have signalled the dispersion of the deep arctic cod aggregations. This close association between arctic cod and their zooplankton prey observed in the AL, including transient incursions in the colder PH, in Amundsen Gulf strongly suggests that prey distribution is a key factor explaining the distribution at depth of arctic cod during winter. Along with the relatively high level of activity measured in lower trophic levels under the winter ice cover, arctic cod actively pursued its zooplankton prey, likely fuelling winter spawning under the ice cover.

\subsection{Spatial variability in benthic processes and pelagic-benthic coupling}

Benthic carbon remineralization and its coupling to pelagic processes in the Canadian Arctic has been resolved in: (1) the Beaufort Shelf (Renaud et al. 2007a; Renaud et al. 2007b), (2) Amundsen Gulf (Forest et al. 2011; Link et al. 2011) and (3) northern Baffin Bay (Grant et al. 2002). Despite its importance for pelagic processes, benthic remineralization of other nutrients (e.g. silicic acid and phosphate) has not been studied in the Canadian Arctic until the IPY. Furthermore, the partitioning of carbon remineralization by different organisms changes with community composition (Piepenburg 2005; Renaud et al. 2007a) and so does partitioning of nutrient remineralization (Michaud et al. 2009). Considering the accumulating evidence for the high variability in biodiversity-ecosystem function relationships, it seems premature to define biological hotspots by their diversity or productivity alone. A description should also include the processes within the benthos and encompass vulnerability to changes in diversity (Kenchington et al. 2011).

\subsubsection{Zooplankton mediation of benthic processes in the Beaufort Sea}

The detailed study of the pelagic-benthic system in the southeastern Beaufort Sea over several months during CFL revealed a weak coupling for the central Amundsen Gulf, which was characterized by high pelagic turnover of a relatively high primary production $(52.5 \pm$ $12.5 \mathrm{~g} \mathrm{C} \mathrm{m}^{-2}$ ) in 2008 (Forest et al. 2011). In the same year, an upwelling event strongly increased primary production in the westernmost opening of the Gulf and on the Mackenzie Shelf, and strong coupling translated into high benthic activity and fresh algae material in the seafloor in 2008 (Tremblay et al. 2011).

Benthic carbon remineralization in the southeastern Beaufort Sea ranged from 11.6 to $207.9 \mathrm{mg} \mathrm{C} \mathrm{m}^{-2} \mathrm{~d}^{-1}$ in 2008 (Fig. 5a). Repeated sampling at five sites revealed a significant increase in benthic carbon cycling over the spring-summer transition (Link et al. 2011). This benthic activity also differed significantly among sites, with the lowest values observed in the central Amundsen Gulf, and the highest in Franklin Bay (Link et al. 2011) and off the Mackenzie Delta (Tremblay et al. 2011). The spatial pattern of benthic carbon 

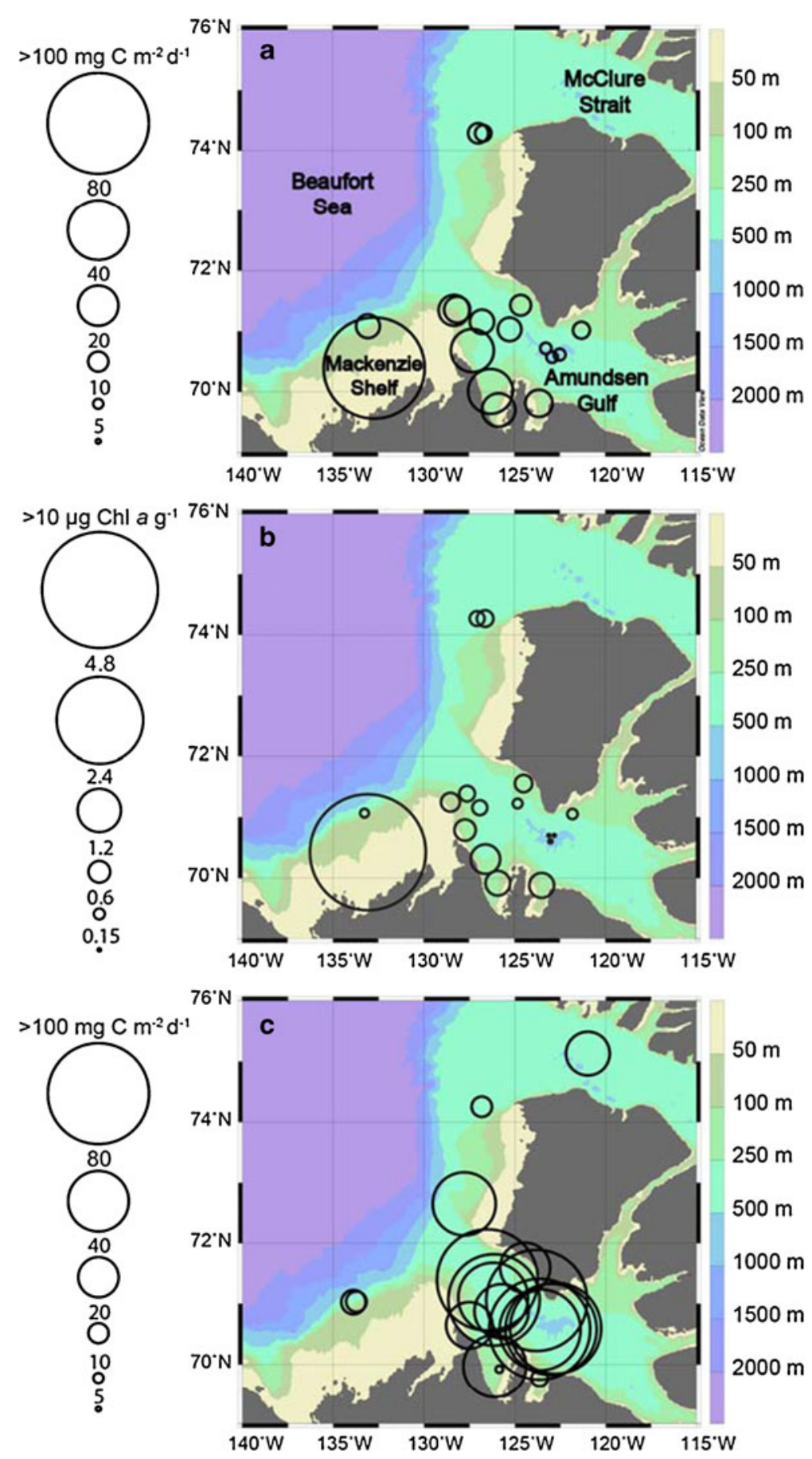

Fig. 5 Spatial distribution of a benthic respiration, b sediment Chl $a$ concentration and $\mathbf{c}$ vertically-integrated zooplankton community respiration in the south-eastern Beaufort Sea from the onset of the period of high biological production (as indicated by ice melt, phytoplankton bloom, and completion of zooplankton spring upward migration) to the end of the CFL zooplankton sampling (28 April to 30 July, 2008) (Link et al., in prep) 
remineralization is in accordance with the spatial pattern of sediment $\mathrm{Chl} a$ concentration (Figs. 5b). However, the high primary production, low benthic activity and sediment pigments in the central Amundsen Gulf (Forest et al. 2011), and the high primary production, high benthic activity and sediment pigments on the eastern Mackenzie Shelf (Fig. 5a and b; Tremblay et al. 2011) suggest that differences in water column processes create spatial heterogeneity in pelagic-benthic coupling in the southeastern Beaufort Sea. Such variability is apparent in the spatial pattern of zooplankton respiration in the southeastern Beaufort Sea in 2008 (Fig. 5c). In Amundsen Gulf, the areas deeper than $250 \mathrm{~m}$ exhibited higher zooplankton respiratory carbon loss $\left(95.6 \pm 28.3 \mathrm{mg} \mathrm{C} \mathrm{m}^{-2} \mathrm{~d}^{-1}\right)$ than shallower areas and sites surrounding the gulf $\left(35.2 \pm 19.4 \mathrm{mg} \mathrm{C} \mathrm{m}^{-2} \mathrm{~d}^{-1}\right)$ throughout the essentially ice-free spring to summer period. Thus, the pattern of pelagic carbon remineralization mediated by zooplankton seems to be the opposite of the one for benthos. Furthermore, the comparison between zooplankton carbon ingestion at depth and POC sampled by short-term sediment traps deployed at $100 \mathrm{~m}$ depth in July 2008 in the central Amundsen Gulf (Forest et al. 2011) revealed that zooplankton had the potential to intercept a major part of the POC before it reached the sea floor (G. Darnis, unpublished data). Much of the carbon ingested by zooplankton was remineralized in the water column. On the other hand, south of Amundsen Gulf, the low zooplankton biomass of Darnley Bay only ingested a small fraction $(<3 \%)$ of the strong new primary production (NPP) resulting from an under-ice bloom in June (Mundy et al. 2009). In this bay shallower than $100 \mathrm{~m}$, benthic Chl $a$ concentration and remineralization were above the average (Fig. 5a and b), indicating that a large fraction of the NPP must have reached the sea floor and most probably led to a tight pelagic-benthic coupling similar to that in Franklin Bay.

\subsubsection{Pelagic-benthic coupling in the eastern Canadian Arctic}

A weak pelagic-benthic coupling in the eastern Canadian Arctic has been assumed following the results from the North Water Polynya (NOW) study in 1997-1998. They showed that the NOW was a hot spot of primary production and among the highest for arctic polynyas. On the other hand, benthic remineralization of ca. $40 \mathrm{mg} \mathrm{C} \mathrm{m}^{-2} \mathrm{~d}^{-1}$ was not high, and close to global averages (Grant et al. 2002; Klein et al. 2002). Results from the ArcticNet 2008 mission, however, yielded higher benthic cycling (average $52-87 \mathrm{mg} \mathrm{C} \mathrm{m}^{-2} \mathrm{~d}^{-1}$ ) (Fig. $6 \mathrm{a}$ and b; Kenchington et al. 2011). This indicates a tighter pelagic-benthic coupling than previously thought, despite comparable sediment Chl $a$ concentration in 1998 and 2008 (average $0.3-2.5 \mu \mathrm{g} \mathrm{g}^{-1}$, Fig. 6c). Considering the high benthic remineralization and late sampling in September 2008, a larger proportion of the photopigments may have already been consumed compared to July 1998 (Link et al. unpublished data). A significant effort was made to measure benthic carbon cycling below $300 \mathrm{~m}$ depth for the first time in the Barrow Strait/Lancaster Sound region. In 2008, two sites in this region had average benthic remineralization of 84 and $47 \mathrm{mg} \mathrm{C} \mathrm{m}^{-2} \mathrm{~d}^{-1}$ per site (Fig. 6b). Sediment Chl $a$ concentrations were 14 and $4 \mu^{-1} g^{-1}$ (Fig. 6c), respectively, and the export of fresh algal material may be among the highest in the Canadian Arctic (Kenchington et al. 2011). Visual examination of sorted sediment samples provided evidence of large $(>1 \mathrm{~mm})$ centric

Fig. 6 a Bathymetry of the Canadian Arctic Archipelago with location of the stations where measurements of benthic carbon, phosphate and silicic acid remineralization, and sediment Chl $a$ concentration were made in 2008. b Benthic carbon and nutrient remineralisation in the Canadian Arctic in 2008. Fluxes are presented as released from the sediments. c Sediment Chl $a$ concentration in the Canadian Arctic in 2008 (solid columns) and in the eastern Arctic in 1998 (hatched columns). Columns represent the medians, and error bars the minimum and maximum values. Note the scale breaks. NOW North Water Polynya. Link et al., in prep 

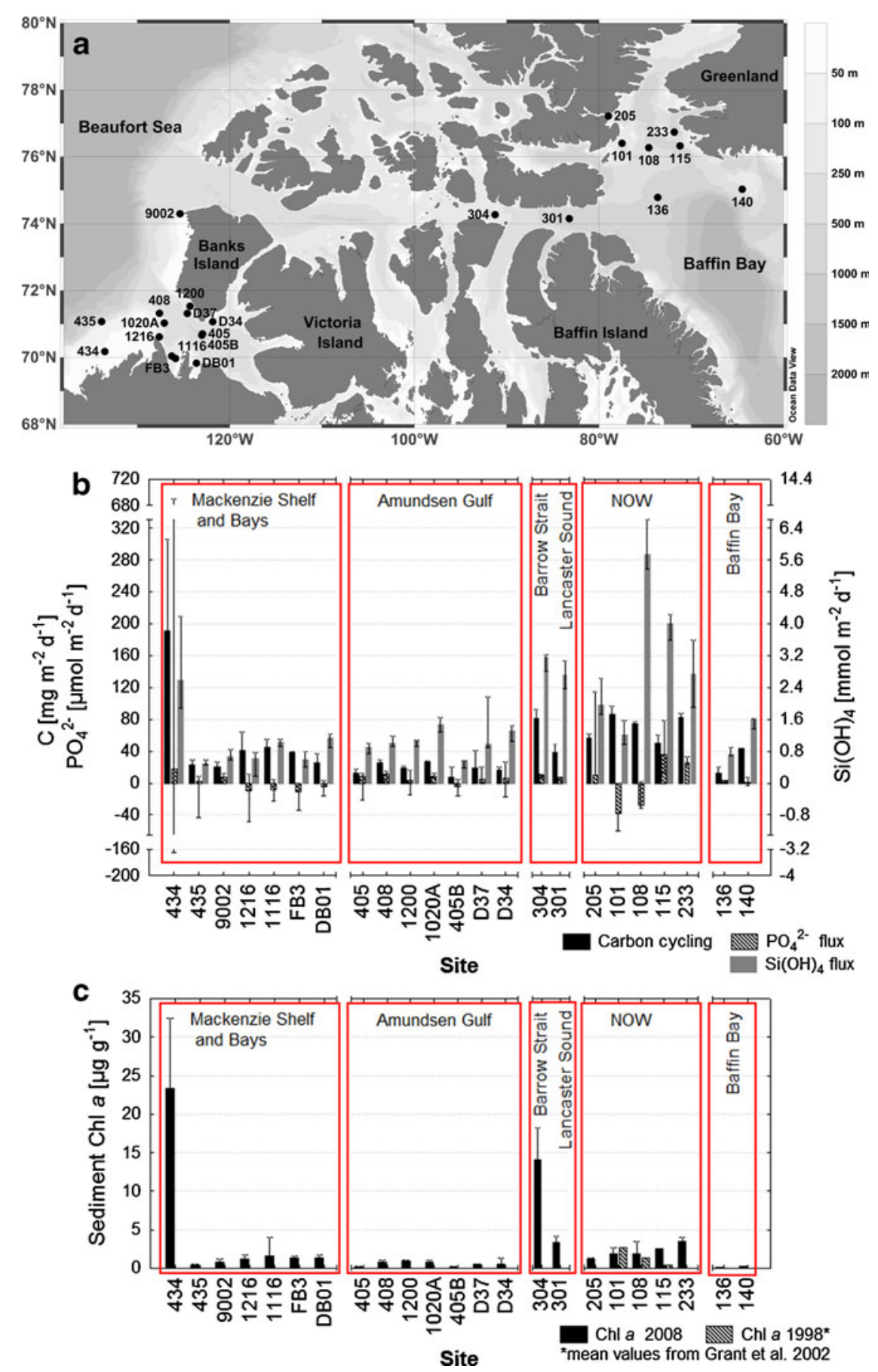
diatoms (Coccinodiscus) being rapidly exported to the seafloor in Barrow Strait (Gaillard et al., unpublished data).

\subsubsection{Hot spots of benthic functioning in the Canadian Arctic}

Biological productivity is often used to measure ecosystem functioning. In benthic environments, however, the remineralization of detritus and release of inorganic nutrients back into the water column are other important processes for the functioning of marine ecosystems. In 2008, the IPY-CFL and associated ArcticNet campaigns allowed us to obtain data on benthic nutrient remineralization from the Canadian Arctic. The highest carbon remineralization rates were recorded in the Mackenzie Delta and Barrow Strait/Lancaster Sound (38$306 \mathrm{mg} \mathrm{C} \mathrm{m}^{-2} \mathrm{~d}^{-1}$ ), whereas slightly lower carbon fluxes were measured in the NOW and Cape Bathurst polynyas and surrounding bays (28-97 $\mathrm{mg} \mathrm{C} \mathrm{m}^{-2} \mathrm{~d}^{-1}$ ) (Fig. 6b). The lowest carbon recycling occurred in central Amundsen Gulf and central Baffin Bay (5-40 mg C m ${ }^{-2}$ $\left.\mathrm{d}^{-1}\right)$. Remineralization of silicic acid was higher in Barrow Strait/Lancaster Sound and the NOW region $\left(1.0-6.6 \mathrm{mmol} \mathrm{Si}(\mathrm{OH})_{4} \mathrm{~m}^{-2} \mathrm{~d}^{-1}\right)$ than in the western Canadian Arctic $(0.2-$ $\left.4.2 \mathrm{mmol} \mathrm{Si}(\mathrm{OH})_{4} \mathrm{~m}^{-2} \mathrm{~d}^{-1}\right)$. Phosphate fluxes were more heterogeneous and no specific pattern was observed (Fig. 6b).

A multivariate approach (one-way PERMANOVA) revealed spatial differences in silicic acid, phosphate and carbon benthic fluxes among the regions delineated in Fig. $6(P<0.01)$. Pair-wise tests showed first that the Mackenzie Shelf and Bays differed significantly from the Amundsen Gulf, Lancaster Sound region and NOW. Second, the NOW was significantly different from the Amundsen Gulf, central Baffin Bay and Mackenzie Shelf. Finally, Lancaster Sound was significantly different from the Amundsen Gulf, central Baffin Bay and the Mackenzie Shelf. Considering the quantity of single fluxes, these significant differences among regions define the NOW and Lancaster Sound at regions of significantly higher nutrient remineralization and therefore unique hotspots of benthic functioning.

Hotspots of macrobenthic production or diversity have been identified within these two areas and the Mackenzie Shelf, but little of the data has been published to date in peer-review journals. Thomson (1982) reported that macrofaunal abundance and taxonomic richness was higher in shallow areas of Lancaster Sound compared to regions west of Barrow Strait and east of Lancaster Sound. In the NOW, individual abundance and species diversity is highest in the center (Lalande 2003). Over the Mackenzie Shelf, Conlan et al. (2008) reported that abundance was high at Cape Bathurst and in the Mackenzie Canyon, with diversity values comparable to the southwestern Beaufort Shelf region. This strongly supports the hypothesis that higher diversity provides for stronger ecosystem functioning, such as higher nutrient remineralization. However, further analyses are necessary to understand the relationships linking species diversity, species identity, functional diversity and ecosystem functioning, as well as how shifts in community composition will influence the performance of the Canadian arctic ecosystem.

\subsection{Canadian Arctic marine biodiversity}

Our knowledge of the Canadian Arctic has increased tremendously during the last decade as a result of increased sampling effort made possible by a dedicated research icebreaker (CCGS Amundsen) and the emergence of major scientific programs (e.g. CASES, ArcticNet, CFL, CHONe, C3O, IPY, Arctic Census of Marine Life). However, biodiversity of many taxonomic groups remains relatively unknown in Canadian arctic waters (Archambault et al. 2010), including areas of the High Arctic where biological data are almost nonexistent (Piepenburg et al. 2011). To remedy that, four major international (Census of Marine Life; http://www.coml.org/; 
O’Dor et al. 2010) and national (ArcticNet; CHONe; Canadian Healthy Oceans Network; http://www.marinebiodiversity.ca/CHONe) programs collaborated to compile biodiversity data in Canada's oceans (Archambault et al. 2010). Here we present the main discoveries for the Canadian Arctic that emerged during the IPY, and we compare Arctic (including the subarctic Hudson Bay system) biodiversity to that of the Atlantic and Pacific oceans.

\subsubsection{Sympagic algae and phytoplankton}

The classic impression of the arctic marine ecosystem is that it is biologically poorly diversified. However, the compilation of Archambault et al. (2010) for many trophic groups, and that of Poulin et al. (2011) for pelagic and sympagic unicellular eukaryotes, revealed that the Arctic is more diverse than expected and that we need to revise this paradigm. Poulin et al. (2011) reported a total number of 1,874 taxa of phytoplankton organisms and 1,027 sympagic unicellular eukaryotes for the whole Arctic. More than half of these taxa $(1,350)$ occur in the Canadian Arctic, compared to 1,128 in the Russian Arctic, 754 off Scandinavia and 443 in Alaskan waters. The number of microalgal taxa recorded so far in the Canadian Arctic exceeds those recorded in the more extensively studied Canadian Atlantic and Pacific coastal systems (Table 1). These results highlight the great biodiversity of primary producers in Canadian Arctic waters compared to surrounding boreal systems.

\subsubsection{Benthic infauna}

A relatively high diversity in benthic infaunal organisms was also observed in the Canadian Arctic, compared to the Canadian Atlantic and Pacific coasts (Table 1). The low historic sampling effort (1955-1977 period) in the Canadian Arctic (see compilation in Cusson et al. 2007), equivalent to $\sim 52 \mathrm{~m}^{2}$ of seafloor, comprised 992 taxa. This compares to 1044 taxa compiled on the Atlantic coast with a three times larger sampling effort $\left(\sim 178 \mathrm{~m}^{2}\right)$. In the last three years, extensive sampling in the Canadian Arctic allowed us to increase resolution from 992 to 1,307 taxa (Snelgrove et al. 2012). Furthermore, Archambault et al. (2010) reported 306 polychaetes species for the whole Canadian Arctic, but a recent study based on a molecular phylogenetic approach identified more than 407 polychaetes species for the western Canadian Arctic only (Carr 2011). These results also highlight that, when comparing the polychaete species rarefaction curves for the Canadian Arctic (897 predicted) and the Canadian Atlantic

Table 1 Number of marine taxa, organised in major taxonomic groups, in the three ocean provinces of Canada

\begin{tabular}{|c|c|c|c|c|}
\hline & $\begin{array}{l}\text { Eastern } \\
\text { Canada }\end{array}$ & $\begin{array}{l}\text { Canadian } \\
\text { Arctic }\end{array}$ & $\begin{array}{l}\text { Western } \\
\text { Canada }\end{array}$ & References \\
\hline $\begin{array}{l}\text { Phytoplankton/ } \\
\text { Ice algae* }\end{array}$ & 626 & $1,002+348^{*}$ & 482 & Poulin et al. (2011) \\
\hline Benthic infauna & 1,044 & 1,307 & 814 & Archambault et al. (2010); Snelgrove et al. (2012) \\
\hline Macroalgae & 350 & 210 & 650 & $\begin{array}{l}\text { South and Tittley (1986); Scagel et al. (1993); } \\
\text { Mathieson et al. (2010) }\end{array}$ \\
\hline Pelagic microbes & - & $9,500-54,000$ & - & Archambault et al. (2010); Lovejoy et al. (2011) \\
\hline Zooplankton & 381 & 372 & 481 & Archambault et al. (2010) \\
\hline Fish & 527 & 189 & 371 & $\begin{array}{l}\text { Coad and Reist (2004); McAllister (1990); } \\
\text { Jørgensen et al. (2005) }\end{array}$ \\
\hline Mammals & 30 & 24 & 37 & Archambault et al. (2010); Schipper et al. (2008) \\
\hline
\end{tabular}


(550 predicted), polychaete richness may actually be higher in the Arctic than in the Atlantic. The observed number of polychaetes species is relatively high for the limited number of samples from the Canadian Arctic when compared to inventories for the pan-arctic shelf $(<500 \mathrm{~m}$; Piepenburg et al. 2011) or deep sea ( $>500 \mathrm{~m}$; Bluhm et al. 2011b). According to the rarefaction curves, the shelves off West and North Greenland and North Labrador are characterized by the highest diversity for four taxonomic groups (Mollusca, Arthropoda, Echinodermata and Annelida) (Piepenburg et al. 2011). A subsequent multivariate one-way analysis of similarity (ANOSIM) based on the presence/absence data tested the significance of differences in infaunal assemblage composition among the three Canadian oceans. Pair-wise comparisons revealed significant differences among all three oceans (Arctic vs Atlantic: $R=$ 0.182, $P=0.02$; Arctic vs Pacific: $R=0.451, P=0.02$; Atlantic vs Pacific: $R=0.19, P=0.02$ ). However, many taxonomic groups (e.g., microscopic Nematoda and other meiofauna) have currently been assessed only at a coarse taxonomic level, and unexplored habitats such as intertidal areas, hard substrata on the seafloor and the deep-sea Canada Basin likely harbour many more undescribed species. These results show that the arctic benthic infauna is more diverse than expected and that biodiversity of some groups is clearly underestimated.

\subsubsection{Macroalgae}

Macroalgae are found in the euphotic and in the intertidal zone, subject to continuous ice scouring that could explain the relatively small number of species (210) observed in the Canadian Arctic compared to 350 and 650 species for the Atlantic and Pacific coasts, respectively (Table 1) (Archambault et al. 2010; Scagel et al. 1993; South and Tittley 1986). In the Eastern Canadian Arctic, Mathieson et al. (2010) compared the species composition of seaweeds in four areas (Ellesmere Island to Baffin Island, Hudson Strait, Hudson Bay, and James Bay). Their results showed a decrease in the number of species from Ellesmere-Baffin area (133 species), Hudson Strait (106 species), Hudson Bay (81 species), and James Bay (47 species) for a total of 164 taxa. The low number of taxa observed in James Bay is presumably due to low salinities associated with high freshwater discharge, as well as heavy ice scouring in the muddy substrata. They also observed an invasive species (Dumontia contorta) from Europe, which was recorded both in James Bay and the Ellesmere-Baffin area.

\subsubsection{Microbes}

The first census of arctic bacteria was realized in 2002 (Bano and Hollibaugh 2002) and since then several studies have been carried out in the Canadian Arctic focusing on small $(<$ $3 \mu \mathrm{m}$ ), single-celled eukaryotic plankton, archaea and bacteria (Galand et al. 2009a; Galand et al. 2009b). More recently, new technology, such as massive parallel tag sequencing techniques (Sogin et al. 2006) have revealed that, like other oceans, the Arctic contains a very diversified pool of microbes (Galand et al. 2009b). Based on this technique, the total microbial diversity in the Canadian Arctic was estimated to comprise between 9,500 and 54,500 taxa (Archambault et al. 2010). In a recent study, Lovejoy et al. (2011) also estimated that the number of picoplankton (archaea, picoeukaryotes and bacteria) operational taxonomic units (OTUs) comprises $\sim 45,000$ taxa in the Arctic Ocean.

\subsubsection{Zooplankton}

Zooplankton communities of the seasonally and perennially ice covered seas are not as well resolved as those of temperate latitudes. Despite relatively low sampling effort, zooplankton 
revealed a surprisingly high diversity in the Canadian Arctic relative to the Atlantic and Pacific coasts of Canada, respectively (Table 1). Thousands of tons of zooplankton are advected annually from the south into the northern Bering and southern Chukchi seas (e.g. Hopcroft et al. 2010). Pacific species were commonly detected in the southern Chukchi Sea, but less frequently with distance from the Bering Strait. Hierarchical cluster analysis of species composition of samples collected during $\mathrm{C} 3 \mathrm{O}$ showed a high degree of similarity between zooplankton communities of the northern Bering and Chukchi Sea shelves, consistent with the high south to north flows through the Bering Strait and into the Chukchi Sea.

\subsubsection{Fish and marine mammals}

Fish and marine mammals constitute the two best-resolved groups when considering biodiversity. Along with macroalgae, these two groups were less diversified in the Arctic relative to lower latitudes of the Pacific and Atlantic coasts of Canada (Table 1). Coad and Reist (2004) evaluated that the Arctic is inhabited by 189 fish species, a number well under the 527 and 371 species on the Atlantic and Pacific coasts, respectively (McAllister 1990). The 242 fish species listed in the pan-Arctic review of Mecklenburg et al. (2011) still represent a much less diverse assemblage than those of the Canadian Atlantic and Pacific waters. However, Chernova (2011) evaluated that 455 marine fish species distribute in the Arctic, including 64 endemic species. In the Canadian Arctic, sampling effort is clearly insufficient for a precise assessment of fish diversity, and there is a need for developing systematic surveys (McAllister 1990). For instance, knowledge of adult marine and anadromous fish of the Beaufort Sea, which is one of the most studied areas of the Canadian Arctic, is considered a major data gap (ArcticNet 2011). Directed sampling in Baffin Bay and Davis Strait has, however, increased the sampling coverage of deep waters (Jørgensen et al. 2005).

The Canadian Arctic hosts 24 of the 125 marine mammal species of the World Ocean. Sadly, some of these populations/species are considered endangered such as the sei whale Balaenoptera borealis, the freshwater harbour seal Phoca vitulina mellonae, the blue whale Balaenoptera musculus and two populations of beluga Delphinapterus leucas (Carwardine 2002; COSEWIC 2004; Reeves et al. 2002). Several other species are threatened or of special concern (Archambault et al. 2010; Schipper et al. 2008).

\subsection{Marine mammals in the Canadian Arctic: the killer whale and bowhead whale}

Ice-adapted marine mammals, along with humans, are the top consumers in the arctic pelagic food web (Huntington and Moore 2008). These species rely on sea ice for at least part of the year notably as foraging habitat and shelter from predation (Bluhm and Gradinger 2008). Loss of multi-year ice, distributional changes in first-year ice towards high latitudes, and a longer ice-free season will thus impact population dynamics of endemic species and favour the invasion of the habitat by new apex predators.

\subsubsection{Climate change and the diet of bowhead whales}

An IPY research project was designed to understand the feeding ecology and spatialtemporal foraging behaviour of the eastern Canada-west Greenland bowhead whale (Balaena mysticetus) population. The bowhead whale is the only mysticete species endemic to the Arctic. This long-lived species ( $>200$ years) is sexually mature at around 25 years of age and has a low fecundity combined with long inter-birth interval (George et al. 1999). 
These particular biological characteristics make this species more vulnerable to climate change, increased exposure to predation by killer whales and human activities (e.g., shipping, mining, oil and gas industry) within its feeding and nursing grounds (Higdon and Ferguson 2009; IPCC 2007).

Based on resource selection functions to evaluate seasonal selection of ice (coverage, thickness, and floe size), Ferguson et al. (2010b) showed that sea ice was a major factor influencing bowhead whale seasonal distribution. Bowhead whales were found to select relatively low ice coverage, thin ice, and small floe areas in winter close to the maximum ice extent as opposed to summer when whales selected high ice coverage, thick ice, and large floe size areas. Detailed movements and dive behaviour analysis of individual tagged bowhead whales revealed plausible summer feeding areas in the eastern Canadian Arctic. Comparing dive characteristics during two putative modes - transient and resident, Pomerleau et al. (2011a) found that the Gulf of Boothia, with its moderate ice coverage (44-62\%), was used as a summer (July-October) foraging area by all four studied whales even though they were tagged with satellite transmitters in two different regions (Cumberland Sound and Foxe Basin). Feeding occurred only for a short duration in northern Foxe Basin and in Cumberland Sound. All animals transited rapidly through Fury and Hecla Strait, an area of heavy ice coverage (80-98 \%). Whales spent most of their time at shallow depths $(8-16 \mathrm{~m})$ when in resident mode, regardless of time of day, likely feeding on nearsurface aggregations of zooplankton.

Bowhead whales are assumed to feed on pelagic and epibenthic zooplankton in late summer and fall (Finley 2001; Lowry et al. 2004; Pomerleau et al. 2011b), and on pre-ascending diapausing calanoid copepods in late winter and early spring, based on data from Disko Bay, Greenland (Heide-Jørgensen et al. 2012; Laidre et al. 2007). The proportional contribution of various food sources (zooplankton) to the diet of bowhead whales was determined using a Bayesian stable isotope mixing model (SIAR; Parnell et al. 2008). Bowhead whales strongly depend on large arctic calanoid copepods (C. hyperboreus, C. glacialis, M. longa and Paraeuchaeta spp.), mysids, euphausids and chaetognaths (Pomerleau et al., unpublished data). Lancaster Sound, Baffin Bay and the Gulf of Boothia were the three main summer feeding areas used by bowhead whales. Davis Strait and Disko Bay, Greenland, were not used by bowhead whale for foraging, at least not in spring or summer. The diet was also found to vary among groups of individuals, which suggests specialization within bowhead whales as targeted prey were the same regardless of the region exploited. The analysis of individual bowhead whale stomach contents revealed the broad foraging spectrum of bowhead whales including a dominant contribution of the epibenthic mysid species, Mysis oculata, along with arctic copepods Metridia longa and Calanus spp. and the amphipod Themisto spp. and Onisimus spp. (Pomerleau et al. 2011b). The two approaches to diet estimation (stable isotopes and stomach contents) indicate that bowhead whales may feed pelagically and epibenthically and that they strongly depend on large arctic calanoid copepods.

Climate change, through biological and ecological modifications, will affect arctic marine mammals both directly and indirectly (Ragen et al. 2008). The predicted continuous warming trend of the ocean surface temperature is expected to favour the growth of smaller phytoplankton cells (picophytoplankton replacing large diatoms) that in turn would also favour small-sized zooplankton species (Li et al. 2009). How marine mammals will respond to the expected shift towards smaller phytoplankton and smaller zooplankton and a decrease in the lipid-rich food web is unclear. The most significant threats to arctic marine mammals comprise loss of sea ice habitat and its associated highly productive food web along with the increase in anthropogenic activities at high latitudes (Ragen et al. 2008). The effects of declining sea ice on marine mammals are likely to be reflected in the shifting of marine 
mammal populations (or smaller units) to higher latitudes by either direct movement and/or indirect shifts associated with increased mortality and decreased reproduction at lower latitudes, coincident with decreased mortality and increased reproduction at higher latitudes (Tynan and DeMaster 1997). The overall combined effects of environmental perturbations caused by climate change could ultimately result in the displacement of some populations from their current geographical ranges and ultimately in the extinction of some marine mammal species (Kovacs et al. 2010). Considering the apparent importance of the Gulf of Boothia and Lancaster Sound as summer feeding areas for the eastern Canada-west Greenland bowhead whale population, as indicated by recent IPY results, every effort should be made to maintain the integrity of these ecosystems by limiting additional environmental alterations and human activities within their critical habitat.

\subsubsection{Killer whale as a new apex predator}

During the course of IPY, the Global Warming and Marine Mammals (GWAMM) project, led by Fisheries and Oceans Canada, aimed to develop community-based monitoring of marine mammal populations in the greater Hudson Bay region. One of the main objectives of the project consisted in detecting changes in the marine ecosystem using apex predators and identifying the drivers of observed changes in order to provide information to policy makers. In this context, a study to document the occurrence and movements of killer whales (Orcinus orca) in the eastern Arctic was initiated. The decreasing trend in arctic sea ice extent and quality (Gagnon and Gough 2005) is expected to have profound effects on habitat use and movement patterns of bowhead whales, as well as other species including their predators (killer whales). The longer open water season in the eastern Arctic has resulted in an increase in killer whales sightings by northerners during recent years (Higdon and Ferguson 2009). Killer whales are known to prey on bowhead, seals, narwhal and beluga. In a warming arctic scenario, this cosmopolitan species may become the "new" arctic apex predator replacing polar bears in areas with reduced sea ice (Ferguson et al. 2010a). Movement analysis of one satellite-tracked killer whale travelling as part of a group of $20+$ killer whales showed that the whale remained in Prince Regent Inlet and in the northern part of the Gulf of Boothia from late August until early October, when locations overlapped aggregations of marine mammal prey species, including seals, narwhal, and bowhead whales (Matthews et al. 2011). Killer whales departed the Arctic Archipelago a few days before the formation of heavy $(+50 \%)$ ice cover in the area, which suggests that killer whales seasonally leave the eastern Canadian Arctic as sea ice advances (Matthews et al. 2011).

\section{Conclusion}

Research conducted through Canadian IPY projects led to several major discoveries that provided baseline information on the spatio-temporal variability in the state of the food web under the ice cover in winter; the state of marine biodiversity; the location and functioning of areas characterized by strong pelagic-benthic coupling; and the distribution and diet of marine mammals. The wealth of new IPY data and knowledge expected to arise throughout the coming years will help with anticipating the impacts of climate change on the structure of arctic marine ecosystems and subsequently on the services that these ecosystems, with their related fauna, provide to Northerners.

The biological results from Canadian IPY programs are challenging two longstanding paradigms in polar biological oceanography. The first considered that the food web remained 
dormant for the largest portion of the winter under the ice cover. Data gathered during the IPY-CFL overwintering survey in the Amundsen Gulf, however, revealed relatively high activity in several trophic levels during winter. At low trophic levels, bacterioplankton and heterotrophic alveolates remained productive despite the lack of primary production (e.g. Forest et al. 2011; Sala et al. 2008; Terrado et al. 2009). Among the zooplankton, detritivorous components of the small size fraction $(<1000 \mu \mathrm{m})$ fed and reproduced actively during the same period whereas the large fraction resumed high metabolic activity in late March, well before the spring release of ice algae and phytoplankton bloom. Further research should help determine the potential sources of energy fuelling these dynamic winter plankton communities. But in light of the present results, we hypothesize that arctic zooplankton populations are well adapted to variability in the timing of the primary production season and that extreme mismatch between primary production and secondary production is unlikely. Finally, populations of adult arctic cod remained closely associated with their mesozooplankton prey in the deep water layers throughout winter (Geoffroy et al. 2011). This strongly suggests that arctic cod actively feed in winter, partly fuelling their spawning.

New IPY studies also provided useful insights on benthic processes and the coupling between pelagic production and benthic carbon turnover. It was found that tight pelagicbenthic coupling and consequent recycling of nutrients at the seafloor characterize specific regions of the Canadian Arctic, such as the North Water polynya and Lancaster Sound. The latter constitute hot spots of benthic ecosystem functioning compared to regions where zooplankton-mediated processes weaken the pelagic-benthic coupling.

The other paradigm being challenged by the outcome of IPY projects is the classic idea that the arctic marine ecosystem is characterized by low biodiversity. A large-scale literature review, combined with recent taxonomic efforts, revealed that biodiversity in the arctic marine ecosystem compares well with that of coastal areas of the Canadian Atlantic and Pacific oceans and there is clear indication that many more species await discovery (Archambault et al. 2010; Piepenburg et al. 2011). However, arctic endemic species are threatened by the expected shift in primary production regime from large to small cells, which might well favour new energy pathways by which carbon is transferred to higher trophic levels by small copepod species of subarctic origin and fish such as capelin (Mallotus villosus) which is able to prey efficiently on small zooplankton. Expected changes in the zooplankton assemblage would primarily affect the vertebrate species that rely almost strictly on Calanus copepods, such as the bowhead whale (Pomerleau et al., unpublished data) or the little auk, Alle alle (Fort et al. 2010; Karnovsky et al. 2010). An objective of the IPY-C3O project was to monitor the penetration of subarctic Pacific fauna into the Canada Basin. Dominant Pacific mesozooplankton species were detected as far as in the Canada Basin. There was however no sign of successful settlement of any Pacific pelagic species in the western Canadian Arctic. Another threat to biodiversity may come from the killer whale (Orcinus orca) as a new apex predator. The killer whale is a voracious predator for most marine mammals, including the bowhead whale, narwhal and beluga, which were only hunted by Inuit until the arrival of a new carnivore. Killer whales are now invading the Canadian Arctic where they forage in groups of over 20 individuals during the ice-free season, and will thus contribute to increasing predation pressure on higher trophic levels as summer ice cover retreats (Matthews et al. 2011). Killer whale movements and occurrence will continue to be monitored in upcoming years to understand better their impacts on the arctic marine food web structure. Such studies conducted as part of IPY highlight the substantial gaps in current taxonomic knowledge and species distribution, and the need for better information to guide further conservation actions in the rapidly changing arctic marine ecosystem. 
Acknowledgments We thank the officers and crews of the CCGS Amundsen, Sir Wilfrid Laurier and Louis S. St-Laurent for their assistance at sea. We are grateful to the numerous colleagues and friends that contributed to the sampling and laboratory analyses or provided essential ancillary data. Special thanks to Alexandre Forest for his great help in designing the arctic marine food web presented in this work. Jill Watkins and Scot Nickels, who have acted as editors for the collection of IPY papers, provided constructive comments that contributed much to the improvement of the manuscript. We gratefully acknowledge the support provided by the Canadian IPY office and particularly Tanuja Kulkarni (Aboriginal Affairs and Northern Development Canada). The CFL, C3O and GWAMM programs were funded by the Canadian International Polar Year (IPY) program office, the Natural Sciences and Engineering Research Council of Canada (NSERC), the Canada Research Chairs (CRC) Program and the Canada Foundation for Innovation (CFI). This work is a joint contribution to the Network of Centres of Excellence ArcticNet, Québec-Océan, the Canadian Healthy Ocean Network (CHONe), ISMER and the Canada Research Chair on the response of marine arctic ecosystems to climate warming.

Open Access This article is distributed under the terms of the Creative Commons Attribution License which permits any use, distribution, and reproduction in any medium, provided the original author(s) and the source are credited.

\section{References}

Alonso-Saez L, Galand PE, Casamayor EO, Pedros-Alio C, Bertilsson S (2010) High bicarbonate assimilation in the dark by Arctic bacteria. ISME J 4:1581-1590

Arashkevich E, Wassmann P, Pasternak A, Riser CW (2002) Seasonal and spatial changes in biomass, structure, and development progress of the zooplankton community in the Barents Sea. J Mar Sys 38:125-145

Archambault P, Snelgrove PVR, Fisher JAD, Gagnon JM, Garbary DJ, Harvey M, Kenchington EL, Lesage V, Levesque M, Lovejoy C, Mackas DL, McKindsey CW, Nelson JR, Pepin P, Piche L, Poulin M (2010) From sea to sea: Canada's three oceans of biodiversity. PLoS One 5:e12182. doi:12110.11371/ journal.pone.0012182

ArcticNet (2011) Beaufort Regional Environmental Assessment (BREA). Beaufort Sea Data Mining Project Report. Québec, Canada, 156 pp.

Ashjian CJ, Campbell RG, Welch HE, Butler M, Van Keuren D (2003) Annual cycle in abundance, distribution, and size in relation to hydrography of important copepod species in the western Arctic Ocean. Deep-Sea Res Part I-Oceanogr Res Pap 50:1235-1261

Auel H, Hagen W (2002) Mesozooplankton community structure, abundance and biomass in the central Arctic Ocean. Mar Biol 140:1013-1021

Bano N, Hollibaugh JT (2002) Phylogenetic composition of bacterioplankton assemblages from the Arctic Ocean. Appl Environ Microb 68:505-518

Barber DG, Asplin MG, Gratton Y, Lukovich J, Galley RJ, Raddatz RL, Leitch D (2010) The international polar year (IPY) circumpolar flaw lead (CFL) system study: overview and the physical system. AtmosOcean 48:225-243

Benoit D, Simard Y, Fortier L (2008) Hydroacoustic detection of large winter aggregations of Arctic cod (Boreogadus saida) at depth in ice-covered Franklin Bay (Beaufort Sea). J Geophys Res Ocean 113: C06S90

Benoit D, Simard Y, Gagné J, Geoffroy M, Fortier L (2010) From polar night to midnight sun: photoperiod, seal predation, and the diel vertical migrations of polar cod (Boreogadus saida) under landfast ice in the Arctic Ocean. Polar Biol 33:1505-1520

Bjerregaard P, Johansen P, Mulvad G, Pedersen HS, Hansen JC (2004) Lead sources in human diet in Greenland. Environ Health Perspect 112:1496-1498

Bluhm BA, Gradinger R (2008) Regional variability in food availability for arctic marine mammals. Ecol Appl 18:S77-S96

Bluhm BA, Gradinger R, Hopcroft R (2011a) Editorial - Arctic Ocean diversity: synthesis. Mar Biodiv 41:1-4

Bluhm BA, Ambrose WGJ, Bergmann M, Clough LM, Gebruk AV, Hasemann C, Iken K, Klages M, MacDonald IR, Renaud PE, Schewe I, Soltwedel T, Włodarska-Kowalczuk M (2011b) Diversity of the arctic deep-sea benthos. Mar Biodiv 41:87-107

Carr MC (2011) Polychaete diversity and distribution patterns in Canadian marine waters. Mar Biodiv:DOI 10.1007/s12526-12011-10095-y.

Carwardine M (2002) Whales, dolphins and porpoises. Dorling Kindersley Publishing, New York 
Chernova NV (2011) Distribution patterns and chorological analysis of fish fauna of the Arctic region. J Ichthyol 51:825-924

Coad BW, Reist JD (2004) Annotated list of the Arctic marine fishes of Canada. Can Manuscr Rep Fish Aquat Sci 2674:112

Conlan K, Aitken A, Hendrycks E, McClelland C, Melling H (2008) Distribution patterns of Canadian Beaufort Shelf macrobenthos. J Mar Sys 74:864-886

Conover RJ, Huntley M (1991) Copepods in ice-covered seas - Distribution, adaptations to seasonally limited food, metabolism, growth patterns and life cycle strategies in polar seas. J Mar Sys 2:1-41

COSEWIC (2004) COSEWIC assessment and update status report on the beluga whale Delphinapterus leucas in Canada. Committee on the Status of Endangered Wildlife in Canada. pp. 70.

Cusson M, Archambault P, Aitken A (2007) Biodiversity of benthic assemblages on the Arctic continental shelf: historical data from Canada. Mar Ecol Prog Ser 331:291-304

Dalpadado P (2002) Inter-specific variations in distribution, abundance and possible life-cycle patterns of Themisto spp. (Amphipoda) in the Barents Sea. Polar Biol 25:656-666

Darnis G, Fortier L (2012) Zooplankton respiration and the export of carbon at depth in the Amundsen Gulf (Arctic Ocean). J Geophys Res 117:C04013

Darnis G, Barber DG, Fortier L (2008) Sea ice and the onshore-offshore gradient in pre-winter zooplankton assemblages in southeastern Beaufort Sea. J Mar Sys 74:994-1011

Falk-Petersen S, Mayzaud P, Kattner G, Sargent J (2009) Lipids and life strategy of Arctic Calanus. Mar Biol Res 5:18-39

Ferguson SH, Higdon J, Chmelnitsky EG (2010a) The rise of killer whales as a major Arctic predator. In: Ferguson S, Loseto L, Mallory M (eds) A little less Arctic: Top predators in the world's largest northern inland sea. Hudson Bay, Springer, New York, USA, pp 117-136

Ferguson SH, Dueck L, Loseto LL, Luque SP (2010b) Bowhead whale Balaena mysticetus seasonal selection of sea ice. Mar Ecol Prog Ser 411:285-297

Finley KJ (2001) Natural history and conservation of the Greenland whale, or Bowhead, in the Northwest Atlantic. Arctic 54:55-76

Forest A, Sampei M, Makabe R, Sasaki H, Barber DG, Gratton Y, Wassmann P, Fortier L (2008) The annual cycle of particulate organic carbon export in Franklin Bay (Canadian Arctic): Environmental control and food web implications. J Geophys Res 113:C03S05

Forest A, Tremblay J-É, Gratton Y, Martin J, Gagnon J, Darnis G, Sampei M, Fortier L, Ardyna M, Gosselin M, Hattori H, Nguyen D, Maranger R, Vaqué D, Marrasé C, Pedrós-Alió C, Sallon A, Michel C, Kellogg C, Deming J, Shadwick E, Thomas H, Link H, Archambault P, Piepenburg D (2011) Biogenic carbon flows through the planktonic food web of the Amundsen Gulf (Arctic Ocean): a synthesis of field measurements and inverse modeling analyses. Prog Oceanogr 91:410-436

Fort J, Cherel Y, Harding A, Welcker J, Jakubas D, Steen H, Karnovsky N, Grémillet D (2010) Geographic and seasonal variability in the isotopic niche of little auks. Mar Ecol Prog Ser 414:293-302

Fortier M, Fortier L, Hattori H, Saito H, Legendre L (2001) Visual predators and the diel vertical migration of copepods under Arctic sea ice during the midnight sun. J Plankton Res 23:1263-1278

Gagnon AS, Gough WA (2005) Climate change scenarios for the Hudson Bay region: an intermodel. Clim Change 69:269-297

Galand PE, Casamayor EO, Kirchman DL, Potvin M, Lovejoy C (2009a) Unique archaeal assemblages in the Arctic Ocean unveiled by massively parallel tag sequencing. ISME J 3:860-869

Galand PE, Lovejoy C, Hamilton AK, Ingram RG, Pedneault E, Carmack EC (2009b) Archaeal diversity and a gene for ammonia oxidation are coupled to oceanic circulation. Environ Microbiol 11:971-980

Garneau M-E, Vincent WF, Alonso-Sáez L, Gratton Y, Lovejoy C (2006) Prokaryotic community structure and heterotrophic production in a river-influenced coastal arctic ecosystem. Aquat Microb Ecol 42:27-40

Garneau ME, Roy S, Lovejoy C, Gratton Y, Vincent WF (2008) Seasonal dynamics of bacterial biomass and production in a coastal arctic ecosystem: Franklin Bay, western Canadian Arctic. J Geophys Res 113: C07S91

Geoffroy M, Robert D, Darnis G, Fortier L (2011) The aggregation of polar cod (Boreogadus saida) in the deep Atlantic layer of ice-covered Amundsen Gulf (Beaufort Sea) in winter. Polar Biol 34:1959-1971

George J, Bada J, Zeh J, Scott L, Brown S, O’Hara T, Suydam R (1999) Age and growth estimates of bowhead whales (Balaena mysticetus) via aspartic acid racemization. Can J Zool 77:571-580

Go YB, Oh BC, Terazaki M (1998) Feeding behavior of the poecilostomatoid copepods Oncaea spp. On chaetognaths. J Mar Sys 15:475-482

Gradinger RR, Bluhm BA (2004) In-situ observations on the distribution and behavior of amphipods and Arctic cod (Boreogadus saida) under the sea ice of the High Arctic Canada Basin. Polar Biol 27:595-603

Grant J, Hargrave B, MacPherson P (2002) Sediment properties and benthic-pelagic coupling in the North Water. Deep-Sea Res Part II-Top Stud Oceanogr 49:5259-5275 
Green EP, Dagg M (1997) Mesozooplankton associations with medium to large marine snow aggregates in the northern Gulf of Mexico. J Plankton Res 19:435-447

Heide-Jørgensen MP, Garde E, Nielsen NH, Andersen ON, Hansen SH (2012) Biological data from the hunt of bowhead whales in West Greenland 2009 and 2010. J Cetacean Res Manage, in press.

Higdon JW, Ferguson SH (2009) Loss of Arctic sea ice causing punctuated change in sightings of killer whales (Orcinus orca) over the past century. Ecol Appl 19:1365-1375

Hirche H-J (1997) Life cycle of the copepod Calanus hyperboreus in the Greenland Sea. Mar Biol 128:607618

Hirche H-J, Kosobokova K (2011) Winter studies on zooplankton in Arctic seas: the Storfjord (Svalbard) and adjacent ice-covered Barents Sea. Mar Biol 158:2359-2376

Hirche H-J, Niehoff B (1996) Reproduction of the Arctic copepod Calanus hyperboreus in the Greenland Seafield and laboratory observations. Polar Biol 16:209-219

Hopcroft RR, Kosobokova KN, Pinchuk AI (2010) Zooplankton community patterns in the Chukchi Sea during summer 2004. Deep-Sea Res Part II-Top Stud Oceanogr 57:27-39

Hovelsrud GK, McKenna M, Huntington HP (2008) Marine mammal harvests and other interactions with humans. Ecol Appl 18:S135-S147

Huntington HP, Moore SE (2008) Assessing the impacts of climate change on Arctic marine mammals. Ecol Appl 18:S1-S2

IPCC (2007) Climate Change 2007: The Physical Science Basis. In: Solomon S, Qin M, Manning Z, Marquis M, Averyt K, Tignor M, Miller H (eds) Contribution of Working Group I to the Fourth Assessment Report of the Intergovernmental Panel on Climate Change. Cambridge University Press, Cambridge, p 996

Jørgensen OA, Hvingel C, Møller PR, Treble MA (2005) Identification and mapping of bottom fish assemblages in Davis Strait and southern Baffin Bay. Can J Fish Aquat Sci 62:1833-1852

Karnovsky N, Harding A, Walkusz W, Kwaśniewski S, Goszczko I, Wiktor JJ, Routti H, Bailey A, McFadden L, Brown Z, Beaugrand G, Grémillet D (2010) Foraging distributions of little auks Alle alle across the Greenland Sea: implications of present and future Arctic climate change. Mar Ecol Prog Ser 415:283-293

Kattner G, Albers C, Graeve M, Schnack-Schiel SB (2003) Fatty acid and alcohol composition of the small polar copepods, Oithona and Oncaea: indication on feeding modes. Polar Biol 26:666-671

Kenchington E, Link H, Roy V, Archambault P, Siferd T, Treble M, Wareham V (2011) Identification of Mega- and Macrobenthic Ecologically and Biologically Significant Areas (EBSAs) in the Western, Central and Eastern Canadian Arctic. Can Sci Advis Sec Res Doc 2011/071.

Kirchman DL (2002) The ecology of Cytophaga-Flavobacteria in aquatic environments. FEMS Microbiol Ecol 39:91-100

Kirchman DL, Moran XAG, Ducklow H (2009) Microbial growth in the polar oceans - role of temperature and potential impact of climate change. Nat Rev Microbiol 7:451-459

Klein B, LeBlanc B, Mei Z-P, Beret R, Michaud J, Mundy CJ, von Quillfeldt CH, Garneau M-È, Roy S, Gratton Y, Cochran JK, Bélanger S, Larouche P, Pakulski JD, Rivkin RB, Legendre L (2002) Phytoplankton biomass, production and potential export in the North Water. Deep-Sea Res Part II-Top Stud Oceanogr 49:4983-5002

Kovacs K, Lydersen C, Overland J, Moore SE (2010) Impacts of changing sea-ice conditions on Arctic marine mammals. Mar Biodiv 41:181-194

Laidre KL, Heide-Jørgensen MP, Nielsen TG (2007) Role of the bowhead whale as a predator in West Greenland. Mar Ecol Prog Ser 346:285-297

Lalande C (2003) Composition et structure de la communauté benthique et quantification de la bioturbation dans la polynie des Eaux du Nord. M.Sc. thesis, Université du Québec à Rimouski, Rimouski, 118 pp

Li WKW, McLaughlin FA, Lovejoy C, Carmack EC (2009) Smallest algae thrive as the Arctic Ocean freshens. Science 326:539

Link H, Archambault P, Tamelander T, Renaud PE, Piepenburg D (2011) Spring-to-summer changes and regional variability of benthic processes in the western Canadian Arctic. Polar Biol 34:2025-2038

Lovejoy C, Potvin M (2011) Microbial eukaryotic distribution in a dynamic Beaufort Sea and the Arctic Ocean. J Plankton Res 33:431-444

Lovejoy C, Vincent WF, Bonilla S, Roy S, Martineau MJ, Terrado R, Potvin M, Massana R, Pedros-Alio C (2007) Distribution, phylogeny, and growth of cold-adapted picoprasinophytes in arctic seas. J Phycol 43:78-89

Lovejoy C, Galand P, Kirchman D (2011) Picoplankton diversity in the Arctic Ocean and surrounding seas. Mar Biodiv 41:5-12

Lowry LF, Sheffield G, George JC (2004) Bowhead whale feeding in the Alaskan Beaufort Sea, based on stomach contents analysis. J Cetacean Res Manage 6:215-233

Mathieson AC, Moore GE, Short FT (2010) A floristic comparison of seaweeds from James Bay and three contiguous Northeastern Canadian Arctic sites. Rhodora 112:396-434 
Matthews CJD, Luque SP, Petersen SD, Andrews RD, Ferguson SH (2011) Satellite tracking of a killer whale (Orcinus orca) in the eastern Canadian Arctic documents ice avoidance and rapid, long-distance movement into the North Atlantic. Polar Biol 34:1091-1096

McAllister DE (1990) A list of the fishes of Canada. Syllogeus - Natl Mus Nat Sci 64:1-310

Mecklenburg CW, Møller PR, Steinke D (2011) Biodiversity of arctic marine fishes: taxonomy and zoogeography. Mar Biodiv 41:109-140

Michaud E, Desrosiers G, Aller RC, Mermillod-Blondin F, Sundby B, Stora G (2009) Spatial interactions in the Macoma balthica community control biogeochemical fluxes at the sediment-water interface and microbial abundances. J Mar Res 67:43-70

Morata N, Renaud PE, Brugel S, Hobson KA, Johnson BJ (2008) Spatial and seasonal variations in the pelagic-benthic coupling of the southeastern Beaufort Sea revealed by sedimentary biomarkers. Mar Ecol Prog Res 371:47-63

Mueller R, Brown R, Hop H, Moulton L (2006) Video and acoustic camera techniques for studying fish under ice: a review and comparison. Rev Fish Biol Fish 16:213-226

Mundy CJ, Gosselin M, Ehn J, Gratton Y, Rossnagel A, Barber DG, Martin J, Tremblay JE, Palmer M, Arrigo KR, Darnis G, Fortier L, Else B, Papakyriakou T (2009) Contribution of under-ice primary production to an ice-edge upwelling phytoplankton bloom in the Canadian Beaufort Sea. Geophys Res Lett 36:L17601

Nishibe Y, Ikeda T (2008) Metabolism and elemental composition of four oncaeid copepods in the western subarctic Pacific. Mar Biol 153:397-404

O’Dor R, Miloslavich P, Yarincik K (2010) Marine biodiversity and biogeography - regional comparisons of global issues, an introduction. PLoS One 5:e11871. doi:11810.11371/journal.pone.0011871

Parnell A, Inger R, Bearhop S, Jackson AL (2008) SIAR: Stable isotope analysis in R. http://cran.rproject.org/web/packages/siar/index.html. Accessed 3 May 2012

Piepenburg D (2005) Recent research on Arctic benthos: common notions need to be revised. Polar Biol 28:733-755

Piepenburg D, Archambault P, Ambrose WG, Blanchard A, Bluhm BA, Carroll ML, Conlan KE, Cusson M, Feder HM, Grebmeier JM, Jewett SC, Lévesque M, Petryashev VV, Sejr MK, Sirenko BI, WłodarskaKowalczuk M (2011) Towards a pan-Arctic inventory of the species diversity of the macro- and megabenthic fauna of the Arctic shelf seas. Mar Biodiv 41:51-70

Pomerleau C, Patterson TA, Luque S, Lesage V, Heide-Jørgensen MP, Dueck L, Ferguson SH (2011a) Bowhead whale (Balaena mysticetus) diving and movement patterns in the Eastern Canadian Arctic: Implications for foraging ecology. Endang Species Res 15:167-177

Pomerleau C, Wocjiech W, Ferguson S (2011b) Stomach contents of bowhead whales (Balaena mysticetus) from four locations in the Canadian Arctic. Polar Biol 34:615-620

Poulin M, Daugbjerg N, Gradinger R, Ilyash L, Ratkova T, von Quillfeldt C (2011) The pan-Arctic biodiversity of marine pelagic and sea-ice unicellular eukaryotes: a first-attempt assessment. Mar Biodiv 41:13-28

Prokopowicz AJ, Rueckert S, Leander BS, Michaud J, Fortier L (2010) Parasitic infection of the hyperiid amphipod Themisto libellula in the Canadian Beaufort Sea (Arctic Ocean), with a description of Ganymedes themistos sp. n. (Apicomplexa, Eugregarinorida). Polar Biol 33:1339-1350

Radulovici AE, Archambault P, Dufresne F (2010) DNA barcodes for marine biodiversity: moving fast forward? Diversity 2:450-472

Ragen TJ, Huntington HP, Hovelsrud GK (2008) Conservation of Arctic marine mammals faced with climate. Ecol Appl 18:166-174

Reeves RR, Stewart BS, Clapham PJ, Powell JA (2002) Marine mammals of the world. Chanticleer Press, Inc, New York

Renaud PE, Morata N, Ambrose WG, Bowie JJ, Chiuchiolo A (2007a) Carbon cycling by seafloor communities on the eastern Beaufort Sea shelf. J Exp Mar Biol Ecol 349:248-260

Renaud PE, Riedel A, Michel C, Morata N, Gosselin M, Juul-Pedersen T, Chiuchiolo A (2007b) Seasonal variation in benthic community oxygen demand: a response to an ice algal bloom in the Beaufort Sea, Canadian Arctic? J Mar Sys 67:1-12

Retamal L, Vincent WF, Martineau C, Osburn CL (2007) Comparison of the optical properties of dissolved organic matter in two river-influenced coastal regions of the Canadian Arctic. Estuar Coast Shelf Sci $72: 261-272$

Rokkan Iversen K, Seuthe L (2011) Seasonal microbial processes in a high-latitude fjord (Kongsfjorden, Svalbard): I. Heterotrophic bacteria, picoplankton and nanoflagellates. Polar Biol 34:731-749

Sala MM, Terrado R, Lovejoy C, Unrein F, Pedros-Alio C (2008) Metabolic diversity of heterotrophic bacterioplankton over winter and spring in the coastal Arctic Ocean. Environ Microbiol 10:942949 
Scagel RF, Gabrielson PW, Garbary DJ, Golden L, Hawkes MW, Lindstrom SC, Oliveira JC, Widdowson TB (1993) A synopsis of the benthic marine algae of British Columbia southeast Alaska. University of British Columbia Press, Vancouver, Washington and Oregon

Schipper J, Chanson JS, Chiozza F, Cox NA, Hoffmann M, Katariya V, Lamoreux J, Rodrigues ASL, Stuart SN, Temple HJ, Baillie J, Boitani L, Lacher TE, Mittermeier RA, Smith AT, Absolon D, Aguiar JM, Amori G, Bakkour N, Baldi R, Berridge RJ, Bielby J, Black PA, Blanc JJ, Brooks TM, Burton JA, Butynski TM, Catullo G, Chapman R, Cokeliss Z, Collen B, Conroy J, Cooke JG, da Fonseca GAB, Derocher AE, Dublin HT, Duckworth JW, Emmons L, Emslie RH, Festa-Bianchet M, Foster M, Foster S, Garshelis DL, Gates C, Gimenez-Dixon M, Gonzalez S, Gonzalez-Maya JF, Good TC, Hammerson G, Hammond PS, Happold D, Happold M, Hare J, Harris RB, Hawkins CE, Haywood M, Heaney LR, Hedges S, Helgen KM, Hilton-Taylor C, Hussain SA, Ishii N, Jefferson TA, Jenkins RKB, Johnston CH, Keith M, Kingdon J, Knox DH, Kovacs KM, Langhammer P, Leus K, Lewison R, Lichtenstein G, Lowry LF, Macavoy Z, Mace GM, Mallon DP, Masi M, McKnight MW, Medellín RA, Medici P, Mills G, Moehlman PD, Molur S, Mora A, Nowell K, Oates JF, Olech W, Oliver WRL, Oprea M, Patterson BD, Perrin WF, Polidoro BA, Pollock C, Powel A, Protas Y, Racey P, Ragle J, Ramani P, Rathbun G, Reeves RR, Reilly SB, Reynolds JE, Rondinini C, Rosell-Ambal RG, Rulli M, Rylands AB, Savini S, Schank CJ, Sechrest W, Self-Sullivan C, Shoemaker A, Sillero-Zubiri C, De Silva N, Smith DE, Srinivasulu C, Stephenson PJ, van Strien N, Talukdar BK, Taylor BL, Timmins R, Tirira DG, Tognelli MF, Tsytsulina K, Veiga LM, Vié J-C, Williamson EA, Wyatt SA, Xie Y, Young BE (2008) The status of the world's land and marine mammals: diversity, threat, and knowledge. Science 322:225-230

Sherr EB, Sherr BF, Wheeler PA, Thompson K (2003) Temporal and spatial variation in stocks of autotrophic and heterotrophic microbes in the upper water column of the central Arctic Ocean. Deep-Sea Res Part 1Oceanogr Res Pap 50:557-571

Skjoldal HR, Wassmann P (1986) Sedimentation of particulate organic-matter and silicium during spring and summer in lindaspollene, Western Norway. Mar Ecol Prog Ser 30:49-63

Snelgrove PVR, Archambault P, Juniper SK, Lawton P, Metaxas A, Pepin P, Rice JC, Tunnicliffe V (2012) The Canadian Healthy Oceans Network (CHONe): An academic-government partnership to develop scientific guidelines in support of conservation and sustainable usage of Canada's marine biodiversity. Fisheries, in press.

Sogin ML, Morrison HG, Huber JA, Mark Welch D, Huse SM, Neal PR, Arrieta JM, Herndl GJ (2006) Microbial diversity in the deep sea and the underexplored "rare biosphere". Proc Natl Acad Sci USA 103:12115-12120

South GR, Tittley I (1986) A catalogue and distributional index of the benthic marine algae of the North Atlantic Ocean. Huntsman Marine Laboratory, St. Andrews

Stirling I (1997) The importance of polynyas, ice edges, and leads to marine mammals and birds. J Mar Sys 10:9-21

Terrado R, Vincent WF, Lovejoy C (2009) Mesopelagic protists: diversity and succession in a coastal Arctic ecosystem. Aquat Microb Ecol 56:25-39

Terrado R, Medrinal E, Dasilva C, Thaler M, Vincent W, Lovejoy C (2011) Protist community composition during spring in an Arctic flaw lead polynya. Polar Biol 34:1901-1914.

Thomson D (1982) Marine benthos in the eastern Canadian high arctic: multivariate analyses of standing crop and community structure. Arctic 35:61-74

Tremblay J-E, Bélanger S, Barber DG, Asplin M, Martin J, Gagnon J, Fortier L, Darnis G, Gratton Y, Williams WG, Link H, Archambault P, Philippe B, Gosselin M (2011) Climate forcing multiplies biological productivity in the coastal Arctic Ocean. J Geophys Res Lett 38:L18604

Tremblay J-É, Robert D, Varela DE, Lovejoy C, Darnis G, Nelson RJ, Sastri AR (2012) Current state and trends in Canadian Arctic marine ecosystems: I. Primary production. Clim Change: this volume.

Tynan CT, DeMaster DP (1997) Observations and predictions of Arctic climatic change: potential effects on marine mammals. Arctic 50:308-322

Vaqué D, Guadayol O, Peters F, Felipe J, Angel-Ripoll L, Terrado R, Lovejoy C, Pedros-Alio C (2008) Seasonal changes in planktonic bacterivory rates under the ice-covered coastal Arctic Ocean. Limnol Oceanogr 53:2427-2438

Welch H, Bergmann M, Siferd T, Martin K, Curtis M, Crawford R, Conover R, Hop H (1992) Energy flow through the marine ecosystem of the Lancaster Sound region, Arctic Canada. Arctic 45:343-357

Wickstead JH (1962) Food and feeding in pelagic copepods. Proc Zool Soc London 139:545-555

Wold A, Darnis G, Søreide J, Leu E, Philippe B, Fortier L, Poulin M, Kattner G, Graeve M, Falk-Petersen S (2011) Life strategy and diet of Calanus glacialis during the winter-spring transition in Amundsen Gulf, Canadian High Arctic. Polar Biol 34:1929-1946

Zeller D, Booth S, Pakhomov E, Swartz W, Pauly D (2011) Arctic fisheries catches in Russia, USA, and Canada: baselines for neglected ecosystems. Polar Biol 34:955-973 